TI 2019-011/V

Tinbergen Institute Discussion Paper
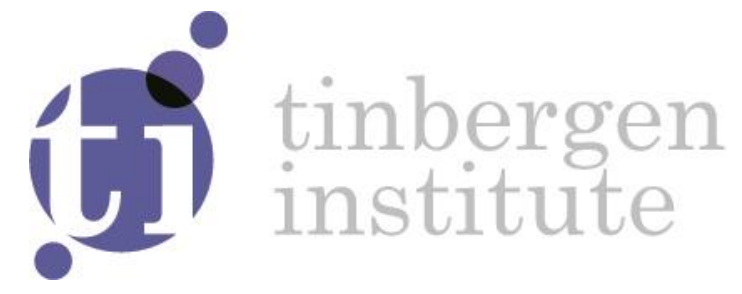

\title{
Unravelling Hidden Inequities in a Universal Public Long-Term Care System
}

Pilar (P.) Garcia-Gomez ${ }^{1}$

Helena M Hernández-Pizarro²

Guillem López-Casasnovas ${ }^{3}$

Joaquim Vidiella-Martin ${ }^{1,4}$

${ }^{1}$ Erasmus School of Economics, Erasmus University Rotterdam, the Netherlands

${ }^{2}$ Center for Research in Health and Economics (CRES), Universitat Pompeu Fabra, Barcelona, Spain

${ }^{3}$ Department of Economics and Business, Universitat Pompeu Fabra, Barcelona, Spain

${ }^{4}$ Tinbergen Institute, Amsterdam, the Netherlands 
Tinbergen Institute is the graduate school and research institute in economics of Erasmus University Rotterdam, the University of Amsterdam and VU University Amsterdam.

Contact: discussionpapers@tinbergen.nl

More TI discussion papers can be downloaded at http://www.tinbergen.nl

Tinbergen Institute has two locations:

Tinbergen Institute Amsterdam

Gustav Mahlerplein 117

1082 MS Amsterdam

The Netherlands

Tel.: +31(0)205984580

Tinbergen Institute Rotterdam

Burg. Oudlaan 50

3062 PA Rotterdam

The Netherlands

Tel.: +31(0)10408 8900 


\title{
Unravelling Hidden Inequities in a Universal Public Long-Term Care System
}

\author{
Pilar García-Gómez ${ }^{1,2, *}$ \\ Helena M Hernández-Pizarro $3,4,5$ \\ Guillem López-Casasnovas ${ }^{3,4}$ \\ Joaquim Vidiella-Martin ${ }^{1,2,4}$
}

January 29, 2019

\begin{abstract}
We investigate whether publicly subsidized long-term care (LTC) is allocated according to needs, independently from income, using administrative data from all applicants for public LTC in Catalonia, from 2011 to 2014 . We measure the level of horizontal inequity in subsidies to compensate informal care costs, formal home care, and institutional care using objective detailed information on needs. Our findings suggest that the system is inequitable; cash transfers are distributed among the financially better-off, while the use of nursing homes is concentrated among the worse-off. Additionally, we assess the inequity in the form of provision (voucher versus inkind) and its implications for the equity in the time to access. Our results show that while in-kind provision is concentrated among the worse-off, the better-off are more likely to receive a voucher to (partly) subsidize LTC expenses. However, this duality does not imply inequity in the time to access a nursing home.
\end{abstract}

Keywords: long-term care, equity, public provision, voucher, in-kind

JEL classification: I14, I38, J14.

\footnotetext{
${ }^{1}$ Erasmus School of Economics, Erasmus University Rotterdam, Rotterdam, the Netherlands

2 Tinbergen Institute, Amsterdam, the Netherlands

3 Department of Economics and Business, Universitat Pompeu Fabra, Barcelona, Spain

${ }^{4}$ Center for Research in Health and Economics (CRES), Universitat Pompeu Fabra, Barcelona, Spain

5 School of Business and Social Science (ESCET), TecnoCampus Mataró affiliated to Universitat Pompeu Fabra, Barcelona, Spain

* Corresponding author. Department of Applied Economics. Erasmus School of Economics. Erasmus University Rotterdam. PO Box 1738. 3000 DR Rotterdam, The Netherlands. E-mail: garciagomez@ese.eur.nl
}

\begin{abstract}
The authors are thankful to Dolores Jiménez Rubio, Cristina Hernández Quevedo, Marianne Tenand, and participants at the $42^{n d}$ Symposium of Spanish Economic Association (SAEe), the Spanish Health Economics Association annual meeting (Jornadas AES), and the Health Economics PhD meeting at the Erasmus University Rotterdam for their useful comments and suggestions. We would also like to thank Cecilia Fabregas, Inma Palet, Nuria Claros and the rest of the team of Dependency at Catalan Government Department of Work, Social Affairs and Family for the help with data. They have no responsibility over the analysis and conclusions presented in this study. Hernandez-Pizarro and LópezCasasnovas acknowledge financial support from the 'Obra Social La Caixa', the Agencia Estatal de Investigación (AEI) (project ECO2012-37496) and Fondo Europeo de Desarrollo Regional (FEDER)(project ECO2017-88609-R). The usual disclaimer applies.
\end{abstract}




\section{Introduction}

Welfare state interventions for the elderly are traditionally universal. However, new public policies formulated in response to the increasing demands of the ageing population are designed according to explicit proportional universalism criteria (i.e. on a needs basis). One advantage of this design is that it may improve equity, as the resource allocation depends on accurate and precisely measured needs. This is particularly true for the Long-Term Care (LTC) system. ${ }^{1}$ To the best of our knowledge, there is scarce evidence on the extent to which social protection succeeds in allocating LTC resources irrespective of the socioeconomic status of the user. In this study, we evaluate whether publicly subsidized LTC is allocated according to LTC needs, independently from income, in Spain, a country that bases public LTC on the principle of proportional universalism. We focus not only on the equity in the use of different services, but also on the forms of provision and time elapsed between the application date and benefit usage.

In particular, we investigate inequity trends in the use of public LTC in the aftermath of the global financial crisis. The Spanish LTC system provides in-kind benefits and vouchers to access professional LTC services as well as cash transfers to compensate for informal caregiving costs. The system provides medical nursing homes, nursing homes, day care centres, professional home care, and tele-assistance. ${ }^{2}$ We use administrative data on the universe of applicants for public LTC in the north-eastern Spanish region of Catalonia. Our data are unique in two distinct ways. First, they contain detailed information on both the objective measures of LTC needs and socioeconomic status. Second, they include both institutionalised individuals living in a nursing home and noninstitutionalised individuals receiving care at home.

We first measure inequity in the use of several LTC services by year (2011 to 2014) using the corrected concentration index (Erreygers, 2009). By 2011, the Spanish LTC system established in 2007 catered for all levels of needs, except for the least severe. Moreover, our observational time period includes two years before and after the reform of the system (July 2012) impelled by the fiscal austerity caused by the financial crisis. Thus, the present study contributes to the literature by examining inequity trends during the Great Recession. ${ }^{3}$

\footnotetext{
${ }^{1}$ Individuals with LTC needs have a reduced functional capacity, which limits their autonomy to perform basic and instrumental activities of daily living (ADL).

${ }^{2}$ In Spain, the difference between nursing homes and medical nursing homes is the composition of the workforce and therefore type of care provided. Medical nursing homes include 24/7 medical doctors and equipment to provide healthcare, generally palliative care. Moreover, in such centres, the healthcare costs are financed through the National Health System, whereas hotel costs are covered by the LTC system.

${ }^{3}$ This strand of the literature has focused on health and healthcare. Coveney et al. (2016) show that the loss of employment and earnings disproportionally affected the health of the young, which in turn reduced health inequalities
} 
Our results contribute to the scarce literature on equity in the use of LTC (García-Gómez et al., 2015; Costa-Font et al., 2018; Duell et al., 2017; Rodrigues et al., 2018; Carrieri et al., 2017; Tenand et al., 2018). García-Gómez et al. (2015) analyse inequity in LTC use and unmet needs in Spain before the introduction of the universal LTC system. Their results show that formal care services are pro-rich distributed, while intensive informal care provision is pro-poor distributed. Our analysis focuses on a period in which the universal LTC system is fully implemented and also includes the institutionalised population. In addition, we analyse inequity among the population of public LTC users as opposed to the overall population with ADL limitations. Therefore, our estimates provide informative evidence on the extent to which the allocation of LTC public subsidies satisfies the equity criteria. Rodrigues et al. (2018) and Carrieri et al. (2017) analyse equity in home care in several European countries, including Spain, using data from the Survey of Health and Retirement in Europe (SHARE). Their results suggest that professional home care is pro-rich distributed in the majority of the countries. Carrieri et al. (2017) show that this pattern differs between types of home care. In particular, they find personal nursing home care to be equally distributed; but pro-rich inequity in the use of paid domestic care in Continental and Southern Europe, but not in Northern Europe. Duell et al. (2017) look at institutional care in the Dutch public system and find access to nursing home to be equitable, while Tenand et al. (2018) find overall LTC use in the Netherlands to be pro-poor after correcting for needs using and an administrative measure.

In line with previous evidence on LTC use in Spain, we find that public LTC benefits are not equally allocated across socioeconomic groups, except for day care centres. In particular, better-off individuals are more likely to receive a cash transfer to cover informal care costs, whereas the use of formal care services (home care and nursing homes) seems to be more concentrated among the worse-off. The degree of the horizontal inequity in receiving a cash transfer for informal care and nursing homes (the preferred benefits) increased after the austerity measures in July 2012. Indeed, only the trends of tele-assistance and medical nursing homes did not change.

Previous results mask important differences in the form of provision (in-kind vs. voucher) across socioeconomic groups. In particular, we find that while services provided in-kind are concentrated among the worse-off, the better-off are more likely to receive a voucher to cover LTC expenses from their preferred provider. Thus, this study also contributes to the strand of the literature on the forms of the provision of social goods, which has mostly focused on education and healthcare (Cave, 2001; Culyer, 1971). While there is vast evidence on the implications for the efficiency of the form

after the Great Recession in Spain. Abásolo et al. (2017) find that the financial crisis affected access to public health services for the worse-off, notably through reduced access to specialists and lower hospitalisations. 
of provision, research on their equity effects is scarce and inconclusive (Epple et al., 2017). ${ }^{4}$ On the one hand, vouchers may increase competition and the quality of services, which in turn can reduce inequity. On the other hand, vouchers can also increase inequity if the worse-off are poorly informed on how to choose or have the choice restricted due to budget constraints.

This duality in the form of provision may lead to inequity in the quality of care received and waiting times. We cannot test inequity in the quality of care. However, we investigate inequity in the time to access a nursing home as a result of the existence of capacity constraints in the number of public beds or financial constraints faced by the beneficiary. We find that the coexistence of public and private providers does not lead to significantly longer times to access nursing homes among the worse-off.

The rest of this paper is structured as follows. The next section describes the Spanish LTC system and the 2012 austerity reform that took place during the observational period of this study. Section 3 describes the methodology and Section 4 presents the data. In Section 5, the results are discussed. Finally, the main conclusions, policy implications, and limitations are discussed in Section 6.

\section{Institutional Background}

In December 2006, the Spanish government passed the Act on the Promotion of Personal Autonomy and Care of Dependent People (Act 39/2006), termed the LTC Act hereafter. Spain's LTC system is a universal system of public subsidies for LTC, covering individuals with all forms of autonomy loss regardless of the cause or age. Before the LTC Act had been introduced, the public provision of such care was restricted to the most deprived population without family support. Thus, meeting LTC needs remained the family's responsibility for the majority, making informal caregiving the main form of LTC in Spain (García-Gómez et al., 2015). Despite the implementation of the LTC Act, Spanish expenditure levels on LTC are still modest compared to Northern and Central European countries. ${ }^{5}$.

Under national guidelines, the LTC system is implemented regionally. ${ }^{6}$ The system defines

\footnotetext{
${ }^{4}$ Compared with studies testing the effects of vouchers or in-kind in education, few studies assess social and health services (Bergman et al., 2016; Blank, 2000; Emanuel et al., 2005; Hansmann, 1996) and none of these directly investigates LTC.

${ }^{5}$ In 2013, LTC expenditures amount to $0.83 \%$ of the Spanish GDP, compared to Northern European countries with expenditures between $2.5 \%$ and 3\% (Jiménez-Martín et al., 2017).

${ }^{6}$ See Peña-Longobardo et al. (2016) for further details of the implementation.
} 
three dependency grades (moderate or Grade I, severe or Grade II, and major or Grade III), as the intensity of care depends on the level of LTC needs. The new Spanish LTC system was implemented gradually, such that the coverage was extended by grade every two years since 2007, starting with the highest level of need.

The LTC application process is generally started by the elderly's family, and consists of two main steps. ${ }^{7}$ First, the needs of the applicants for LTC benefits are assessed against an official scale (BOE (2007), BOE (2011)). The outcome of this assessment determines the dependency grade. ${ }^{8}$ Second, each grade gives access to a menu of benefits from which the claimant (and/or her family) chooses: tele-assistance, home care, day care centre, nursing homes, medical nursing homes, and a cash transfer for compensating an informal caregiver. All types of care are available for all qualified individuals. ${ }^{9}$ However, the number of hours of care and cash transfer amount depend on the grade assignment. Different care arrangements may also be combined if the claimant remains at home (e.g. day care centres can be combined with tele-assistance or a cash transfer).

The subsidies are partially funded by both the national and the regional governments, $21 \%$ and $61 \%$ on average in Spain respectively, and the rest of the cost is covered by the beneficiary depending on her financial capabilities. In addition, individuals can choose whether to receive the service in-kind or use a voucher to select a private provider from a list of authorised suppliers. In the majority of cases, supply constraints affect the choice of LTC. If the applicant prefers a benefit with a long waiting time, she can opt for another benefit in the meantime. Finally, applicants can ask for reassessment whenever their functional capacity deteriorates. ${ }^{10}$

In July 2012, against the backdrop of fiscal austerity caused by the Great Recession, the government reformed the LTC system, reducing publicly funded LTC expenditure by $20 \%$ per beneficiary BOE (2011). The main changes consisted of a reduction in service intensity (e.g. hours of care, voucher value, and informal care cash transfers) and a $70 \%$ increase in the beneficiary's contribution through cost-sharing. In addition, eligible Grade-I claimants had to wait until 2015 to receive their benefits instead of starting in 2013. These measures did not affect all care options proportionally; indeed, the major cuts were concentrated in cash transfers for informal care. First, individuals who opted for informal care had now to wait two years without any other financial support. Additionally,

\footnotetext{
${ }^{7} \mathrm{GP}$ and social workers can inform and suggest to claim for benefits. In the case of the elderly without relatives, social service can manage the application process on her behalf.

${ }^{8}$ Individuals with no or minimal LTC needs are ineligible for LTC benefits.

${ }^{9}$ One exception is that nursing homes are unavailable for individuals assigned to Grade I.

${ }^{10} 27 \%$ of applicants seek a reassessment in the period we analyse. In addition, although individuals can change the type of benefit, $78 \%$ stick to the initial choice.
} 
the cash transfer was reduced by $15 \%$ and the social security payment for the caregiver, initially included on top of the cash transfer, was also removed.

By December 2015, more than a million-and-a-half people had applied for LTC benefits in Spain. Among those, $55 \%$ were aged 80 or over, representing $31 \%$ of the $80+$ cohort. $^{11}$ Of all claimants whose LTC needs were assessed (93\% from all applications), $78 \%$ are eligible for LTC benefits: $23 \%$ in Grade III, $30 \%$ in Grade II, and 25\% in Grade I. Moreover, $65 \%$ of those eligible had already started receiving benefits (IMSERSO, 2017).

\section{Methodology}

We follow García-Gómez et al. (2015) by measuring the level of horizontal inequity in LTC using the normalisation of the concentration index (CI) suggested by Erreygers (2009) In particular, the corrected concentration index (CCI) for bounded variables ranging from 0 to 1 as LTC use is calculated as follows (Van de Poel et al., 2012):

$$
C C I=4 * \mu * C I(y)
$$

where $\mu$ is the average of the LTC variable, $y$ is the measure of LTC use, and $C I(y)$ is the conventional CI (Wagstaff et al., 1989):

$$
C I=\frac{2}{\mu} \operatorname{cov}\left(y_{i}, R_{i}\right)
$$

where $R_{i}$ is the relative ranking of individuals according to socioeconomic status.

To measure horizontal inequity, we adjust the CCI (i.e. the measure of inequality in LTC use) for the need variables (Kakwani et al., 1997). We assume that $y_{i}$ is a linear and additively separable function of the need $\left(x_{k}\right)$ and non-need $\left(z_{p}\right)$ covariates as follows:

$$
y_{i}=\alpha+\sum_{k} \gamma_{k} x_{k}+\sum_{p} \delta_{p} z_{p}+\varepsilon_{i}
$$

where $\gamma$ and $\delta$ are the vectors of the estimated coefficients from a linear probability model.

\footnotetext{
${ }^{11}$ LTC claimants represent $3.45 \%$ of the Spanish population. Three-quarters are aged 65 and over, which implies that $14 \%$ of the elderly in Spain have claimed such benefits.
} 
Then, the CCI can be expressed as (Van de Poel et al., 2012)

$$
C C I=4 *\left[\sum_{k} \gamma_{k} \mu_{x_{k}} C I_{x}+\sum_{p} \delta_{p} \mu_{z_{p}} C I_{z}+G C_{\varepsilon}\right]
$$

where $\mu_{x_{k}}$ and $\mu_{z_{p}}$ represent the means of the need and non-need variables, respectively, while $C I_{x}$ and $C I_{z}$ are the CIs of these variables regarding socioeconomic status. $G C_{\varepsilon}$ is the generalised CI for the error term. Lastly, we compute horizontal inequity in LTC use (CHI) by subtracting the contribution of the need variables from the CCI:

$$
C H I=C C I-4 * \sum_{k} \gamma_{k} \mu_{x_{k}} C I_{x}
$$

The CHI can take values between -1 and 1 . A value of 0 indicates no inequity overall. Negative values indicate that LTC use is concentrated among the worse-off, while positive values point out that use is concentrated among the better-off.

\section{Data}

\subsection{Sample}

We use administrative data on all LTC applicants in Catalonia. ${ }^{12}$ We focus on individuals aged at least 50, who represent $90 \%$ of all applicants, and the period 2011-2014. We use detailed information on applicants' health status including the degree of autonomy to perform ADL summarised in the needs assessment score and a detailed list of diagnoses coded with the International Classification of Disease Ninth Revision. For each individual, we also observe socioeconomic and demographic characteristics (annual personal income, age, sex, marital status, and place of residence) and the result of the LTC application process (selected care, form of provision (in-kind or voucher), and time to access the service) used as the main outcomes.

We are interested in the evolution of inequity in LTC use within the public system. Therefore, from the universe of applicants, we select those receiving benefits, who represent on average $66 \%$ of

\footnotetext{
${ }^{12}$ Catalonia represents $16 \%$ of the Spanish population, $17 \%$ of all applications, and $16 \%$ of all beneficiaries (IMSERSO, 2017).
} 
all the individuals in the system (see Table A1 in the appendix). ${ }^{13,14}$ We then delete observations with missing information on either income ( $44 \%$ of the sample of beneficiaries) or any other of the relevant variables (additional $6 \%$ of the sample). We cannot estimate any equity index without income, since this is the variable we use to rank individuals by socio-economic status. Moreover, we cannot estimate horizontal equity without the need and non-need variables (see Section 3).

Missing data are due to the inability of some local administrative units to record income, or any other of the relevant variables, in the IT system ${ }^{15}$. A potential concern to our study is thus differential sample selection. If municipalities with a higher concentration of richer (poorer) individuals are more likely to record the data properly, then our sample over-represents rich (poor) individuals and is not representative of the overall population of users. In order to shed some light on this, we test whether the excluded individuals have different observable characteristics compared with the rest of the sample (see Table A2 in the appendix). We find that there are small differences between our sample and the overall population, as the sample with reported income has slightly less females (0.66 vs 0.72$)$ and is healthier (score 66.4 vs 70.5$)$, but in general those differences are fairly small. Therefore, we expect any selection bias in the estimated indices to be relatively small. ${ }^{16}$

\subsection{Variables and Descriptive Statistics}

Table 1 shows the distribution of subsidies by year. Each outcome takes value 1 if the beneficiary receives that subsidy. Informal care cash transfers are the most common LTC service (more than $50 \%$ of users). The second most preferred subsidy is nursing homes (one-fifth). Home care is the third most selected subsidy, while day care centres are only chosen by $5 \%$ of beneficiaries. The take-up rates of home care and day care centres rise over time: the share of beneficiaries that choose them doubles after the 2012 fiscal austerity measures compared with 2011. Finally, tele-assistance represents around $10 \%$ of the subsidies and is often combined with other services (almost $40 \%$ of cases).

\footnotetext{
${ }^{13}$ The other $44 \%$ of claimants are: (i) ineligible for the benefit (15\%), (ii) waiting to receive the benefit (18.5\%), (iii) waiting for a needs assessment $(3.5 \%)$, or (iv) have withdrawn their application (because of death, migration, or other motives) (7\%).

${ }^{14}$ We estimate all indices for each different year included in the analysis (2011-2014). To select the service used during the year, we focus on the type of service the individual uses in February. This selection is convenient because we can consider 2011 and 2012 to be the period previous to the July 2012 austerity reform, while 2013 and 2014 are the post-reform period. In addition, we do not expect this selection to affect our results, as individuals do not change benefits frequently and remain in the LTC system until they die. Moreover, we replicate the analysis using another month, October, and the conclusions do not change. Results available upon request.

${ }^{15}$ Social workers were required to ask all the information to the claimants. However, IT systems were not homogenised at the beginning, and not all units recorded all the assessed information.

${ }^{16}$ Most differences are statistically significant given the large sample size, but they are not economically important
} 
The remaining variables used in the analysis can be grouped into need and non-need variables. Need variables include the score that determines the level of LTC needs, age, sex, labour market disability status, and a detailed list of medical diagnoses. ${ }^{17}$ The main non-need variable is the beneficiary's personal annual income provided by the tax office. For those individuals that do not have to pay income tax, annual personal income is self-reported using bank certificates. On average, annual income is 10,738 euros and only the richest decile has an annual income higher than 18,000 euros (see Table A1). Finally, we also consider marital status, region, and year of application to be non-need variables.

Table 1: Observations by Type of Care

\begin{tabular}{lcccc}
\hline \hline & $(1)$ & $(2)$ & $(3)$ & $(4)$ \\
& 2011 & 2012 & 2013 & 2014 \\
\cline { 2 - 5 } Cash Transfer for Informal Caregiving & 39,246 & 55,974 & 56,927 & 51,364 \\
(Professional) Home Care & 5,918 & 9,122 & 12,200 & 12,765 \\
Day Care Centre & 3,151 & 4,440 & 5,134 & 5,874 \\
Tele-Assistance & 10,036 & 10,693 & 9,145 & 7,570 \\
Nursing Home & 12,977 & 19,708 & 24,368 & 25,288 \\
Medical Nursing Home & 1,174 & 1,645 & 2,023 & 2,103 \\
\hline \hline
\end{tabular}

Table 2 shows the descriptive statistics. ${ }^{18}$ The first column presents the means for the whole sample, and Columns second to forth provide information for the different subsamples of users (informal care, nursing homes, and the rest of the services). Beneficiaries are on average 80 years old and $70 \%$ are women. Care arrangements differ by gender: while men receive informal care, disproportionally more women live in a nursing home. This difference could be driven by the contexts of LTC needs by men and women: women tend to suffer from LTC needs when they are older and widowed, while men become dependent when they are still married (IDESCAT, 2011). More than $20 \%$ of beneficiaries have labour disability status. The geographical distribution is representative of the Catalan territory. Finally, the most common conditions suffered by claimants are circulatory, neurological, musculoskeletal, endocrino-metabolic, and genitourinary diseases and mental disorders.

\footnotetext{
${ }^{17}$ The different diagnoses are grouped into 10 diagnosis groups (see Table A3 in the Appendix).

${ }^{18}$ Tables A.4a-A.4d in the Appendix show descriptive statistics by year.
} 
Table 2: Descriptive Statistics

\begin{tabular}{|c|c|c|c|c|}
\hline & $(1)$ & $(2)$ & $(3)$ & $(4)$ \\
\hline & Sample & Informal Care & Nursing Home & Other \\
\hline \multicolumn{5}{|l|}{ Need Variables } \\
\hline Score & 67.91 & 65.68 & 74.62 & 66.49 \\
\hline Age & 80.19 & 79.50 & 81.81 & 80.23 \\
\hline Gender (female) & 0.70 & 0.67 & 0.74 & 0.70 \\
\hline Physical Disability & 0.15 & 0.18 & 0.07 & 0.16 \\
\hline Intellectual Disability & 0.03 & 0.03 & 0.05 & 0.03 \\
\hline DG: Neurological & 0.49 & 0.46 & 0.57 & 0.49 \\
\hline DG: Circulatory & 0.47 & 0.48 & 0.44 & 0.48 \\
\hline DG: Digestive & 0.02 & 0.02 & 0.02 & 0.02 \\
\hline DG: Muskuloskeletal & 0.43 & 0.44 & 0.41 & 0.46 \\
\hline DG: Endocrino-metabolic & 0.37 & 0.39 & 0.34 & 0.37 \\
\hline DG: Eye & 0.10 & 0.10 & 0.08 & 0.10 \\
\hline DG: Ear & 0.01 & 0.01 & 0.01 & 0.02 \\
\hline DG: Respiratory & 0.18 & 0.20 & 0.15 & 0.18 \\
\hline DG: Genitourinary & 0.31 & 0.33 & 0.29 & 0.31 \\
\hline DG: Mental & 0.27 & 0.26 & 0.30 & 0.26 \\
\hline DG: Development & 0.00 & 0.00 & 0.00 & 0.01 \\
\hline DG: Malformations & 0.00 & 0.00 & 0.00 & 0.00 \\
\hline DG: Cancer & 0.12 & 0.13 & 0.09 & 0.11 \\
\hline DG: Hematological & 0.01 & 0.00 & 0.01 & 0.01 \\
\hline DG: Infectious & 0.01 & 0.01 & 0.01 & 0.01 \\
\hline DG: Dermatological & 0.00 & 0.00 & 0.00 & 0.00 \\
\hline \multicolumn{5}{|l|}{ Non-need Variables } \\
\hline Annual Income & $10,738.35$ & $10,803.35$ & $10,753.89$ & $10,569.90$ \\
\hline Region: Barcelona (city) & 0.27 & 0.24 & 0.25 & 0.36 \\
\hline Region: Barcelonés (county) & 0.22 & 0.20 & 0.26 & 0.22 \\
\hline Region: Rest of BCN (province) & 0.22 & 0.23 & 0.21 & 0.22 \\
\hline Region: Girona & 0.10 & 0.11 & 0.09 & 0.08 \\
\hline Region: Lleida & 0.07 & 0.08 & 0.08 & 0.04 \\
\hline Region: Tarragona & 0.08 & 0.08 & 0.08 & 0.06 \\
\hline Region: Terres de l'Ebre & 0.04 & 0.06 & 0.03 & 0.02 \\
\hline Marital Status: Married & 0.39 & 0.46 & 0.19 & 0.43 \\
\hline Marital Status: Widow & 0.44 & 0.41 & 0.53 & 0.42 \\
\hline Marital Status: Single & 0.09 & 0.06 & 0.16 & 0.07 \\
\hline Marital Status: Other & 0.09 & 0.08 & 0.11 & 0.08 \\
\hline
\end{tabular}

Notes: Other category accounts for Day Care Centre, Home Care, Teleassistance and Medical Nursing Home (all together, they represent less than 28\%). The 7 regions included corresponds to the 7 "geographical units" used by Social Services Department for organizational purposes. Table A.4, in the Appendix presents descriptive statistics by years.

\section{Results}

\subsection{Determinants of the Allocation of Publicly Subsidized LTC}

First, we analyse which need and non-need factors affect the likelihood of choosing a particular LTC option. Table A5 in the Appendix reports the estimated coefficients using a linear probability model. We find that the choice of care depends not only on the individual's level of need, but also on the nonneed variables. The estimated coefficients of the non-need variables show the expected signs. Single and widow individuals have a higher probability of using institutional services and lower probability of care delivered at home (informal care, professional home care, and tele-assistance), compared 
to married ones. The probability that an individual chooses informal care, day care centre, or tele-assistance (home care, nursing home, or medical nursing home) is significantly and positively (negatively) associated with income, although the magnitudes of these coefficients are very small. The region of residence also plays a role in the choice of care, but these magnitudes are again modest.

Regarding the need variables, the coefficients of age, gender, disability status, and score also have the expected signs. All home care arrangements are associated with lower scores (i.e. lower needs), while higher scores positively affect the choice of nursing homes services. In addition, nursing homes are positively associated with age and intellectual disability. On the contrary, physical disability is associated with a higher probability of using informal care and professional home care. The estimated coefficients of the different medical categories show the expected sign, but the magnitudes and significance levels are modest. This is not surprising as LTC needs are rooted in the loss of autonomy to perform ADL, which is captured by the score, while the severity of LTC needs can differ widely among individuals with the same diagnoses.

\subsection{Inequity in LTC Use}

Figure 1 presents the evolution of the inequity indices for all types of LTC. The dashed vertical line indicates the introduction of the austerity reform in July 2012. The estimated CHIs for inequity and CCIs for inequality are reported in A6 in the Appendix. First, there is a clear difference between the services that are pro-poor and pro-rich distributed: nursing homes, medical nursing homes and home care services are more concentrated among the worse-off, while tele-assistance and informal care are pro-rich distributed. Day care centres are equally distributed. Second, horizontal inequity in the use of nursing homes and informal care, which accounts for almost $75 \%$ of the total publicly subsidised care, increases after the 2012 fiscal reform of the system. Indeed, only horizontal inequity in teleassistance and medical nursing homes decreases thorough the study period. Third, the contribution of need to inequality in institutionalised care services is pro-rich (i.e. $C C I>C H I$ ), while the contribution of need to inequality in care delivered at home is pro-poor distributed $(C C I<C H I)$ (see Table A7 in the Appendix for the contribution of need variables vs non-need ones). ${ }^{19}$ These differences are driven by the signs of the estimated coefficients of the need variables (see Section 5.1).

Cash transfers are equitably distributed in 2011, but become concentrated among the better-off thereafter, after controlling for need, following an increasing trend. ${ }^{20}$ One plausible explanation of

\footnotetext{
${ }^{19}$ Our results are robust to including only the score as a need variable, and dropping the medical diagnoses.

${ }^{20}$ Unfortunately, there is no information on the actual number of informal care hours so we cannot test whether the sign reverses for intensive informal care as in García-Gómez et al. (2015).
} 
the increased pro-rich distribution of informal care is the policy design. Informal care is the only subsidy that provides an unconditional cash transfer. Moreover, after the 2012 austerity measures, individuals who opted for informal care had to wait up to two years to start receiving the benefit without any right to recover the amount during the waiting time. We would therefore expect the better-off to be more able to finance the cost of care during these two years.

Nursing homes become slightly more pro-poor distributed in 2014 compared with the previous years. The inverted U-shaped trend of horizontal inequity over the study period indicates a reverse of the pre-2012 reform trend towards inequity. In addition, it is reasonable to expect that any changes in the distribution of nursing home use driven by the 2012 austerity reform only appear with some delay given nursing home waiting lists. Together with day care centres, the trend of inequity in medical nursing homes use does not change after such reform. This is not surprising as individuals are referred to medical nursing homes for recovery after a health shock that requires hospitalisation or for palliative care if terminally ill. All medical costs are thus covered by the healthcare system, while the LTC system only covers the hotel cost.

Home care use is concentrated among the worse-off and the level of inequity increases over the period of our analysis. Finally, tele-assistance is significantly concentrated among the better-off, although it becomes less concentrated over time. 


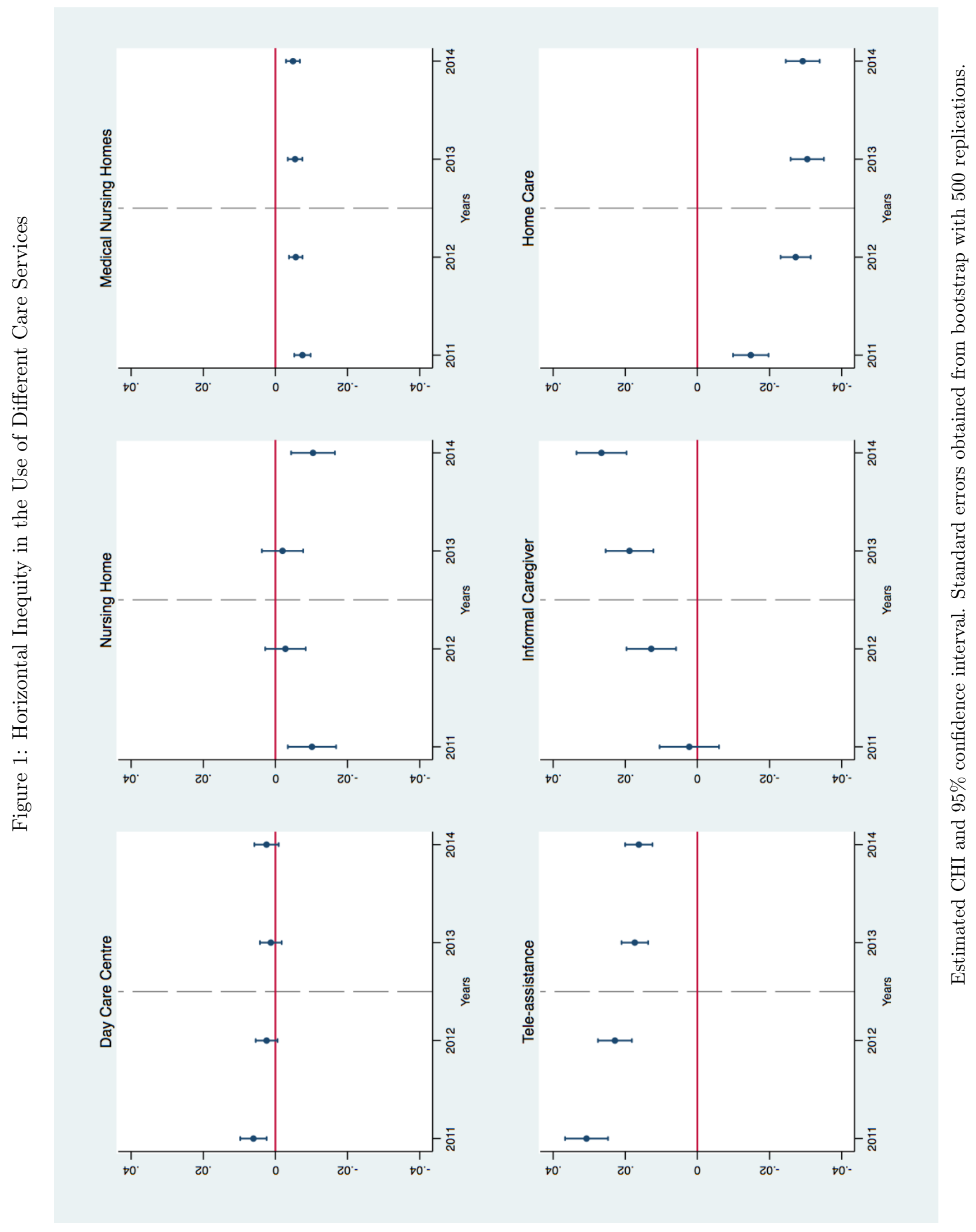




\subsection{Inequity in the Form of LTC Provision}

The LTC Act aimed to support claimants with public services in-kind, but supply shortages (or capacity constraints) forced the introduction of vouchers to acquire services in the private sector. These vouchers can only be used with a selection of private providers who meet certain quality standards (DOGC, 2007). ${ }^{21}$ Indeed, many of these private centres offer private and public services simultaneously. Individuals may decide to receive the subsidy as a voucher or in-kind for reasons other than need, such as the amount of user contribution. Distinctly, this contribution may vary across form of provision depending on the individual's socio-economic status. In particular, the user contribution is higher with a voucher for the worse-off: they have to pay more than $50 \%$ of the nursing home price with the highest voucher, but less than $33 \%$ as cost-sharing if the service is provided in-kind. ${ }^{22}$ Similarly, while the cost-sharing of in-kind services directly depends on the beneficiary's financial capability (up to the point that the better-off could pay $100 \%$ of the service), the voucher for the better-off is $80 \%$ of the amount for the worse-off. ${ }^{23}$

Considering these facts, we create a variable that takes value 1 if care is provided in-kind and 0 otherwise (i.e. a voucher or informal care cash transfer) to test the existence of horizontal inequity in the form of provision. The use of care provided in-kind is concentrated among the worse-off, and this concentration increases over time (see Figure 2 and Panel B of Table A6 in the Appendix). Indeed, the magnitude of the inequity index doubles between 2011 and 2014 (from -0.044 to -0.086 ).

We then analyse inequity in the form of provision by type of service. In particular, we focus on the services that offer such duality: nursing homes, day care centres and home care. ${ }^{24}$ The results in Figure 3 show that the duality in the form of provision of LTC services is mainly driven by the distribution in the form of provision for nursing home. In particular, nursing home use when benefits are provided in-kind are concentrated among the financially worse-off, while vouchers are more often used by the better-off. The pattern of the indices over time is symmetric and inequity increases over time in both cases. Similarly, we find duality in the distribution of home care. Home care provided in-kind is concentrated among the worse-off and the inequity index increases (in absolute value) over

\footnotetext{
${ }^{21}$ Social services authorities check that private providers meet these standards to guarantee the quality of care (see DOGC (2007)). All the selected providers are officially listed. The majority of public beds are managed by private providers, with only $15 \%$ belonging to public entities.

${ }^{22}$ For home care, the highest voucher does not cover $50 \%$ of the service cost. For day care centres, the highest voucher covers a little above $50 \%$ of the cost.

${ }^{23}$ In the absence of vouchers, the better-off could be interested in the service in-kind, although they incur the whole cost because the (regulated) public price is below the market price.

${ }^{24}$ The variables 'Nursing Home - In Kind', 'Day Care Centre - In Kind' and 'Home Care - In Kind' equal 1 if the beneficiary receives the service in-kind and 0 if the service is paid for with a voucher or another benefit is received. Similarly, 'Nursing Home - Voucher', 'Day Care Centre - Voucher', and 'Home Care - Voucher' equal 1 if the service is subsidised by a voucher and 0 otherwise.
} 
time. The CHI for home care via voucher is relatively small, although significant, over the entire period, and the sign changes from negative in the first two years to positive after the 2012 fiscal austerity measures. Likewise, the CHI of day care centre over time remains low when we distinguish by type of provision, although we find that the provision via voucher is slightly more concentrated among the better off through the period. The equitable distribution of day care centres in-kind may be driven by the low demand for this service and/or absence of capacity constraints to receive this service in-kind. ${ }^{25}$

The differences found in the form of provision of nursing home services could translate into differences in the quality of care or waiting times depending on individuals' socioeconomic status. Unfortunately, we cannot test whether there is inequality in the quality of care. However, different facts suggest that there are no large differences in quality by type of provision. First, a voucher does not provide access to the universe of private providers, but only to those that meet certain quality criteria. Second, only $15 \%$ of the beds provided in-kind are in public institutions, while the remaining $85 \%$ are privately managed (Departament de Treball, 2016). In the majority of these cases, the same centre provides private (with or without vouchers) and in-kind services simultaneously. Regardless of who is the main payer (the government in case of in-kind provision of nursing homes and the user for those financed via voucher), the care received in a centre with these two types of services is the same for all residents (e.g. same meals, same professionals, same space). Third, as not all the beds in private institutions would be occupied by private users, private entities have incentives to provide public services. While this minimises the possibility of cream-skimming by nursing home providers, inequalities in the time to access a nursing home are likely for (at least) two reasons. The supply of services provided in-kind is fixed, whereas private services eligible for vouchers have fewer capacity constraints. This could translate into large differences in waiting times. In addition, a voucher together with annual income may not be enough to cover full nursing home costs, so financial constraints can play an important role in the time needed for lower socioeconomic groups to access a nursing home. Because of this, we assess the existence of a socio-economic gradient in the time to access nursing homes in the next section.

\footnotetext{
${ }^{25} 7 \%$ of the available in-kind services at day care centres in 2015 were not taken (López-Casasnovas et al., 2017).
} 
Figure 2: Horizontal Inequity in the Use In-kind Benefits

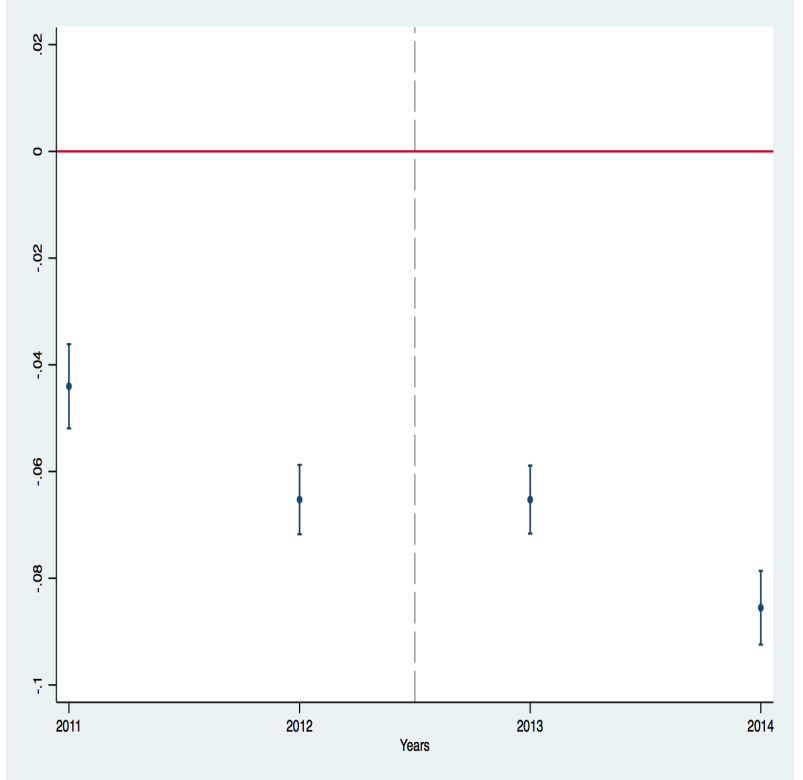

Estimated CHI and 95\% confidence interval. Standard errors obtained from bootstrap with 500 replications. 


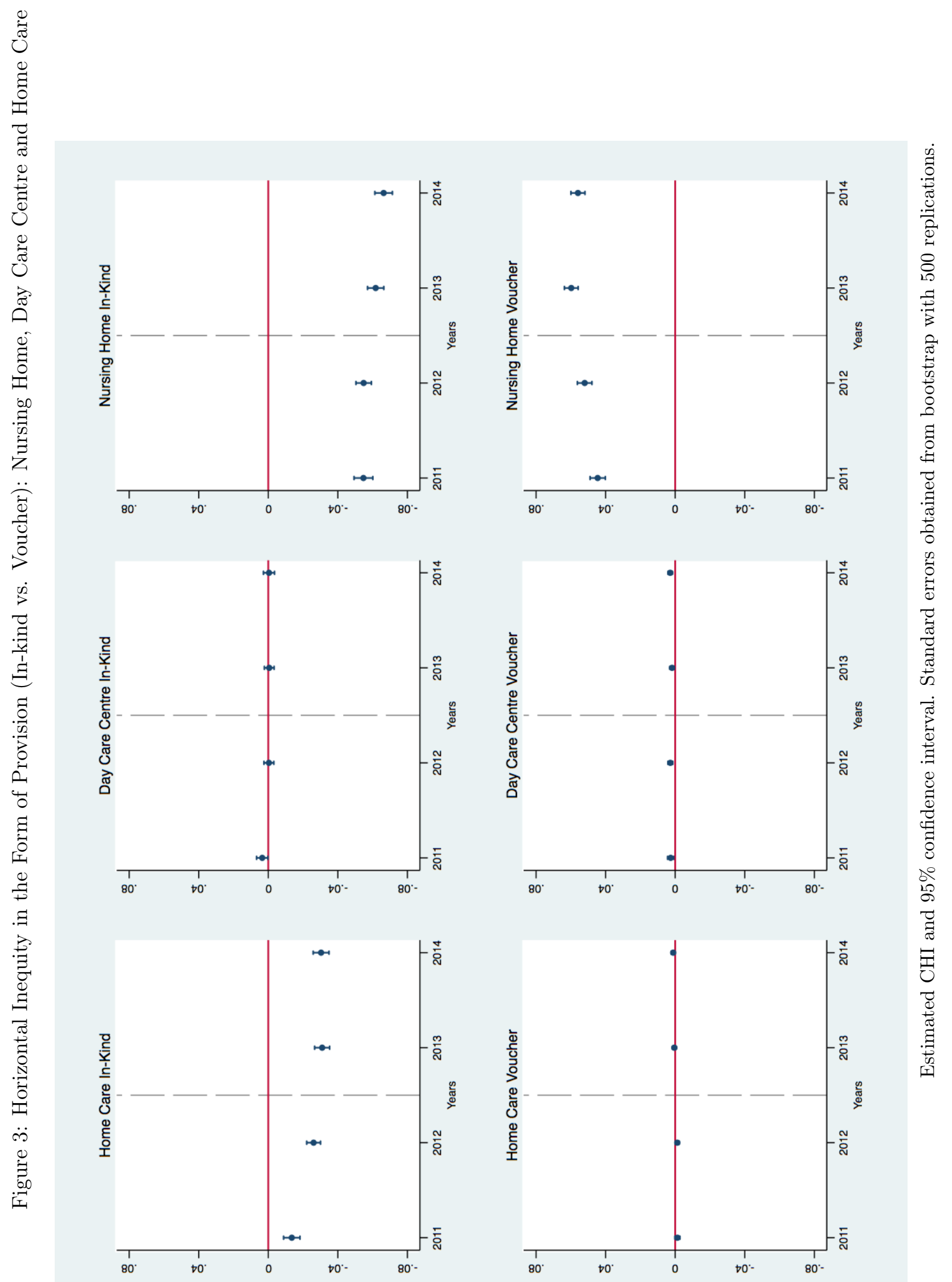




\subsection{Time to Access Nursing Homes}

For every nursing home user, we measure the months between the application date and the day the individual receives the subsidy (i.e. access to a nursing home in-kind or receives the voucher). We exclude individuals that entered into a nursing home in the old system (i.e., before 2007) given the lack of information in the administrative records on the exact procedures (and dates) in the old system. ${ }^{26}$ On average, it takes 20 months for a beneficiary to enter a nursing home since the assessment is made. This time is the combination of both demand and supply factors; delayed entry may arise as a result of: (i) capacity constraints induced by excess demand; (ii) individuals only applying to nursing homes when their condition deteriorates and other services are not enough; or (iii) budget constraints to cover nursing home costs (cost-sharing if in-kind or remaining costs if voucher). Table A8 in the Appendix shows the evolution of the time to access a nursing home.

We first compute the horizontal inequality index $(\mathrm{HI})^{27}$ for the time to access a nursing home. Figure 4 shows the evolution of the horizontal inequity indices regarding the time to access a nursing home. Estimated indices can be found in Table A9 in the Appendix. The estimates show that betteroff individuals wait on average more at the beginning of the period (see the upper-left graph in Figure 4). This initial pro-rich inequity in time to access diminishes over time, until the estimated index becomes equitable by the end of our observation period (2014). In order to prevent our estimates of inequity in the time to access a nursing home from being driven by those who entered the system in the earlier period, we focus on the subsample of individuals that enter into a nursing home in a given year. In particular, we look at the time to access for individuals who were in a nursing home in February in year $t$ but not $t-1$. Therefore, we estimate the inequity using an inflow approach, similar to Siciliani (2016). The estimated horizontal indices show that the pro-rich distribution in the time to access observed in 2011 becomes pro-poor after the 2012 austerity reform, although statistically insignificant in 2014 (see the upper-right graph in Figure 4).

In the previous section (5.3) we document how socio-economic status influences the choice of form of provision. Those who are financially worse-off access the LTC benefits via in-kind provision, whilst wealthier individuals tend to choose a voucher that covers part of the cost. Given this duality, we separate time to access a nursing home according to the form of provision using the inflow approach

\footnotetext{
${ }^{26}$ Before the implementation of the Spanish LTC system, social services at the municipal level provided means-tested nursing homes to elderly citizens with LTC needs. Thereafter, all these individuals were automatically transferred from the old system to the new one without an assessment of their needs or choice of care (i.e. an administrative transfer of records). They appear in our data as having no waiting time to access a nursing home.

${ }^{27}$ In this case a correction is not needed because outcome variables are not bounded between 0 and 1 . The conventional $\mathrm{HI}$ is defined as follows: $H I=C I-\frac{\sum_{k} \gamma_{k} \mu_{x_{k}} C I_{x}}{\mu_{y}}$.
} 
(see bottom panels in Figure 4). While we find no socio-economic gradient in time to access nursing homes via in-kind provision by the end of the period, time to access via voucher is larger for the less wealthy individuals. This suggests that prioritization of waiting lists to access nursing home beds in-kind is appropriately done following criteria based only on need.

Figure 4: Horizontal Inequity in the Time to Access Nursing Home
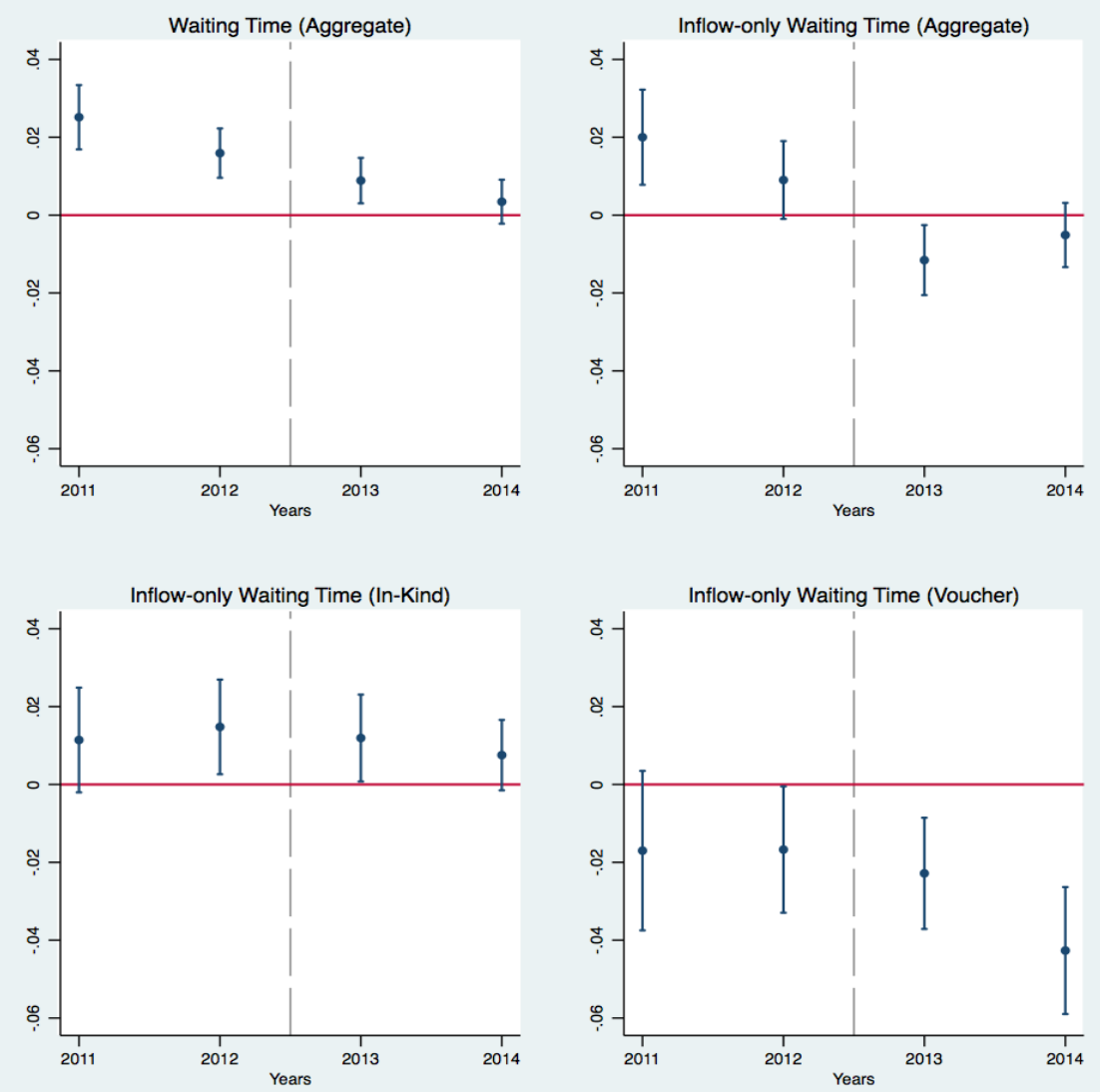

Estimated HI and $95 \%$ confidence interval. Standard errors obtained from bootstrap with 500 replications. 


\section{Discussion}

We analyse whether a system of publicly subsidised LTC allocates care services equally to individuals with the same needs in Spain. We focus on the period 2011 to 2014, were the gradual implementation of Spanish system of universal LTC benefits was completed. These years include a period with austerity measures that reduced the generosity of the system (after July 2012). We find that publicly subsidised care is unequally distributed across socioeconomic groups after adjusting for differences in need. Cash subsidies provided to compensate informal care costs are concentrated among the financially better-off, while the use of nursing homes is concentrated among the worse-off. Day care centres are the only service which is equally distributed across socio-economic groups along the entire period.

Finding concentration of cash transfers to cover informal care costs among the better off contrasts with previous evidence for Spain that finds that informal care, particularly an intensive use of it, is pro-poor distributed (García-Gómez et al., 2015). There exist several potential explanations for these different results. The first one is the sample definition. García-Gómez et al. (2015) analyse inequity in formal and informal care among the full population of non-institutionalised dependent individuals before the implementation of the universal LTC system, while we focus on individuals who have applied for public LTC subsides to cover any kind of care (without accounting for private care to complement publicly subsidised care). Further research should test whether the distribution across socioeconomic groups reverses once individuals become eligible for public support. This would imply that individuals from low socioeconomic groups cover their care needs by using informal care when public support is lacking, but resort to professional home care whenever they have access to the public system. Secondly, we cannot rule out that some individuals use the monetary transfer to pay for formal care outside the public system. This could enhance equity if this consumption frees up resources of a given public system to be used by less well-off individuals (Besley and Coate, 1991), but also have negative equity effects in the long-run if there is a "secession of the wealthy" (CostaFont and Jofre-Bonet, 2008). Similarly, other individuals may complement home care services with unpaid informal care. Thirdly, we can only observe the extensive margin of the provision of informal care, while information on the intensity of informal care provision would add insightful evidence for policy design. Given the concentration of these cash transfers among the better-off LTC users, it is not surprising to find other services, in particular professional home care and nursing homes, concentrated among the worse-off. 
The reform in July 2012 reduced publicly funded LTC expenditure by $20 \%$ per beneficiary, mainly by decreasing service intensity (e.g. hours of care, voucher value, and informal care cash transfer) and increasing by $70 \%$ the beneficiary's contribution through cost-sharing. We find that the level of inequity has increased after the 2012 reform for the two most preferred care options, nursing homes and informal care. Our formal analysis confirms the hypothesis of a reduction in equity of the Spanish public LTC system after the 2012 austerity measures claimed by Peña-Longobardo et al. (2016).

Indeed, the structure of these cash transfers after the austerity reform may incentivise this change, as individuals now need to wait two years before receiving the monetary transfer and its amount was reduced. Therefore, less budget-constrained individuals are more likely to wait for this additional period of time. This hypothesis is aligned with Costa-Font et al. (2018), who find that low and medium income groups disproportionally increased the use of informal care when informalcaregiving cash transfers were introduced. Accordingly, the worse-off would be expected to be more sensitive to the disproportional reduction in the informal care cash transfer after the 2012 reform (compared with the other benefits), which in turn increases the inequity of this type of care.

In addition, we identify inequity in the form of provision: while in-kind provision is concentrated among the worse-off, the better-off are more likely to receive a voucher to partly subsidise LTC expenses from their preferred provider. This duality is driven by beneficiaries at nursing homes. This could further lead to other inequalities. First, one could be concerned about potentially different times to access a nursing home, driven by either demand (mainly through budget constraints) or supply constraints as costs to access a nursing home are higher if voucher for low income individuals compared to in-kind provision, while waiting times are shorter via voucher. Our results show that the distribution of time to access to a nursing home varies over the period of analysis. It is prorich in 2011 but becomes either equally or slightly pro-poor distributed after the 2012 fiscal reform. In addition, we explore the possibility of inequity in time to access a nursing home, separately by form of provision. This distinction reveals that the time to access a nursing home in-kind is not associated to income after controlling for need. This supports the good design and functioning of the prioritization mechanisms to access public beds. On the contrary, longer times to access are concentrated among the worse off for those who opt for vouchers. The fact that there are fewer supply constraints to access a nursing home using a voucher suggests that other mechanisms play a role. In particular, the voucher amount plus the average income of the analysed group is not enough to cover the full cost of a nursing home. Therefore, they need to resort to savings or family solidarity. 
This financial constraint may force the less wealthy to wait longer. Further research should explore the differences in these financial contributions to fully assess the equity implications of this dual system of provision. Moreover, we cannot rule out that other barriers (organizational, cultural, etc) play a role in explaining this differential behaviour. Yet, we cannot test for inequalities in care quality, although the system characteristics suggest them not to be important.

There are two main caveats to our analysis. First, we rank individuals based on annual income, without accounting for wealth. ${ }^{28}$ The extent to which the conclusions would change remains for future research. For example, Rodrigues et al. (2018) compare inequity in LTC by wealth and income using data for the Survey of Health and Retirement in Europe (SHARE), and find that in Spain inequity in home care remains unchanged if wealth is used instead of income and that informal care becomes more pro-poor distributed. In addition, we only measure inequity in public LTC use, and therefore do not consider inequity in other parts of the process. First, there could be socioeconomic differences in the propensity to apply for public LTC benefits if better-off individuals have better access or knowledge about the functioning of the system. Second, we do not observe how applicants cover their LTC needs while waiting to receive the subsidy either in-kind or as a voucher. This is a relevant issue as over 100,000 claimants were waiting in 2015 for a benefit already approved (Jiménez-Martín et al., 2017). Similarly, we do not observe whether (and how) claimants complement their public subsidies with other private formal or informal care options. Notwithstanding these caveats, our results are policy relevant to assess the inequity in the public provision of LTC, and a valuable first step to assess the overall inequity of the public LTC system. Further research should focus on filling the other gaps of evidence as additional data might become available.

In a context where many governments in Europe are forced to reform their LTC system to ensure their sustainability upfront to its expansions given population trends, accounting for the degree of inequity of the system is important. The use of policies that distribute subsidies on needs basis are not enough to ensure equity in the access to LTC. Policy-makers should account for the potential unintended side effects of dualities in the form of provision. Specifically, the impact of co-payments on use, intensity, waiting times and quality should not be disregarded when designing such policies.

\footnotetext{
${ }^{28}$ While the elderly population, especially widows, are quite homogeneous in terms of annual income (low variance in their main source of income, i.e., old-age or survivors pension); the group is more heterogeneous in wealth (real state properties). See for example Sáez et al. (2018).
} 


\section{References}

Abásolo, I., Saez, M., and López-Casasnovas, G. (2017). Financial crisis and income-related inequalities in the universal provision of a public service: the case of healthcare in spain. International Journal for Equity in Health, 16(1):134.

Bergman, M. A., Johansson, P., Lundberg, S., and Spagnolo, G. (2016). Privatization and quality: Evidence from elderly care in Sweden. Journal of Health Economics, 49:109-119.

Besley, T. and Coate, S. (1991). Public provision of private goods and the redistribution of income. The American Economic Review, 81(4):979-984.

Blank, R. M. (2000). When can public policy makers rely on private markets? the effective provision of social services. The Economic Journal, 110(462):34-49.

BOE (2007). Royal Decree 504/2007, of 20th April, which approves the scale to value the dependency situation established by Law 39/2006 of 14th December.

BOE (2011). Royal Decree 174/2011, of 11th February, which approves the scale to value the dependency situation established by Law 39/2006 of 14th December, which promotes the personal autonomy and care to those individuals in dependency situation.

Carrieri, V., Di Novi, C., and Orso, C. E. (2017). Home sweet home? Public financing and inequalities in the use of home care services in Europe. Fiscal Studies, 38(3):445-468.

Cave, M. (2001). Voucher Programmes and their Role in Distributing Public Services. OECD Journal on Budgeting, 1(1):59-88.

Costa-Font, J., Jimenez-Martin, S., and Vilaplana, C. (2018). Thinking of incentivizing care? the effect of demand subsidies on informal caregiving and intergenerational transfers. IZA Discussion Paper 11774.

Costa-Font, J. and Jofre-Bonet, M. (2008). Is there a 'secession of the wealthy'? private health insurance uptake and national health system support. Bulletin of Economic Research, 60(3):265287.

Coveney, M., García-Gómez, P., Van Doorslaer, E., and Van Ourti, T. (2016). Health disparities by income in spain before and after the economic crisis. Health Economics, 25:141-158.

Culyer, A. J. (1971). The nature of the commodity health care and its efficient allocation. Oxford Economic Papers, 23(2):189-211. 
Departament de Treball, A. S. i. F. (2016). Registre d'Entitats, Serveis i Equipaments Socials (RESES).

DOGC (2007). Act 12/2007, of 11th October, Social Services.

Duell, D., Koolman, X., and Portrait, F. (2017). Practice variation in the dutch long-term care and the role of supply-sensitive care: Is access to the dutch long-term care equitable? Health Economics, 26(12):1728-1742.

Emanuel, E., Fuchs, V., et al. (2005). Health care vouchers - a proposal for universal coverage. New England Journal of Medicine, 352(12):1255-60.

Epple, D., Romano, R. E., and Urquiola, M. (2017). School vouchers: A survey of the economics literature. Journal of Economic Literature, 55(2):441-492.

Erreygers, G. (2009). Correcting the concentration index. Journal of Health Economics, 28(2):504515.

García-Gómez, P., Hernández-Quevedo, C., Jiménez-Rubio, D., and Oliva-Moreno, J. (2015). Inequity in long-term care use and unmet need: two sides of the same coin. Journal of Health Economics, 39:147-158.

Hansmann, H. (1996). The changing roles of public, private, and nonprofit enterprise in education, health care, and other human services. In Individual and social responsibility: Child care, education, medical care, and long-term care in America, pages 245-276. University of Chicago Press.

IDESCAT (2011). Cens de població i habitatges. Per sexe, edat quinquennal i estat civil.

IMSERSO (2017). Información estadística del sistema para la autonomía y atención a la dependencia.

Jiménez-Martín, S., Viola, A., et al. (2017). Observatorio de dependencia. segundo informe. FEDEA Report.

Kakwani, N., Wagstaff, A., and Van Doorslaer, E. (1997). Socioeconomic inequalities in health: measurement, computation, and statistical inference. Journal of Econometrics, pages 87-103.

López-Casasnovas, G., Hernández-Pizarro, H., and Meis, U. (2017). Informe Econòmic i Social ACRA 2016. Technical report, CRES-UPF.

Peña-Longobardo, L. M., Oliva-Moreno, J., García-Armesto, S., and Hernández-Quevedo, C. (2016). The Spanish long-term care system in transition: Ten years since the 2006 Dependency Act. Health Policy, 120(10):1177-1182. 
Rodrigues, R., Ilinca, S., and Schmidt, A. E. (2018). Income-rich and wealth-poor? the impact of measures of socio-economic status in the analysis of the distribution of long-term care use among older people. Health Economics, 27(3):637-646.

Sáez, M., Vidiella-Martin, J., and López-Casasnovas, G. (2018). Collateral damages of the great crisis in Spain. A longitudinal health study. UPF Working Paper 1603.

Siciliani, L. (2016). Waiting times: evidence of social inequalities in access for care. Data and Measures in Health Services Research, pages 1-17.

Tenand, M., Bakx, P., and van Doorslaer, E. (2018). Equal long-term care for equal needs with universal and comprehensive coverage?: An assessment using dutch administrative data. Tinbergen Institute Discussion Paper 2018-098/V.

Van de Poel, E., Van Doorslaer, E., and O'Donnell, O. (2012). Measurement of inequity in health care with heterogeneous response of use to need. Journal of Health Economics, 31(4):676-689.

Wagstaff, A., Paci, P., and van Doorslaer, E. (1989). Equity in the finance and delivery of health care: some temptative cross-country comparisons. Oxford Review of Economic Policy, 5 (1):89-112. 


\section{Appendix A Additional Figures and Tables}

Table A1: Sample Size per Year

\begin{tabular}{lcccc}
\hline \hline & $(1)$ & $(2)$ & $(3)$ & $(4)$ \\
& 2011 & 2012 & 2013 & 2014 \\
\cline { 2 - 5 } Registered in the system & 225,112 & 265,131 & 290,156 & 308,568 \\
Claimants with LTC benefits & 165,143 & 188,051 & 189,825 & 179,356 \\
Claimants with benefits: missing income data & 87,038 & 81,935 & 75,728 & 69,864 \\
Claimants with benefits: missing other data & 10,797 & 11,307 & 10,684 & 9,426 \\
Claimants with benefits: in our sample & 67,308 & 94,809 & 103,413 & 100,066 \\
\hline \hline
\end{tabular}

Table A2: Differences in Observables between Subsamples

\begin{tabular}{|c|c|c|c|}
\hline & (1) & $(2)$ & $(3)$ \\
\hline & Mean - without Income & Mean - with Income & P-value \\
\hline \multicolumn{4}{|l|}{ Need Variables } \\
\hline Score & 70.53 & 66.39 & 0.00 \\
\hline Age & 80.70 & 80.95 & 0.00 \\
\hline Gender (female) & 0.72 & 0.66 & 0.00 \\
\hline Physical Disability & 0.02 & 0.03 & 0.00 \\
\hline Intellectual Disability & 0.10 & 0.15 & 0.00 \\
\hline DG: Neurological & 0.49 & 0.53 & 0.00 \\
\hline DG: Circulatory & 0.48 & 0.47 & 0.00 \\
\hline DG: Digestive & 0.02 & 0.03 & 0.00 \\
\hline DG: Muskuloskeletal & 0.38 & 0.46 & 0.00 \\
\hline DG: Endocrino-metabolic & 0.36 & 0.35 & 0.00 \\
\hline DG: Eye & 0.08 & 0.11 & 0.00 \\
\hline DG: Ear & 0.00 & 0.03 & 0.00 \\
\hline DG: Respiratory & 0.16 & 0.19 & 0.00 \\
\hline DG: Genitourinary & 0.27 & 0.32 & 0.00 \\
\hline DG: Mental & 0.25 & 0.26 & 0.00 \\
\hline DG: Development & 0.00 & 0.01 & 0.00 \\
\hline DG: Malformations & 0.00 & 0.00 & 0.00 \\
\hline DG: Cancer & 0.09 & 0.12 & 0.00 \\
\hline DG: Hematological & 0.00 & 0.01 & 0.00 \\
\hline DG: Infectious & 0.01 & 0.01 & 0.00 \\
\hline DG: Dermatological & 0.00 & 0.00 & 0.00 \\
\hline \multicolumn{4}{|l|}{ Non-need Variables } \\
\hline Region: Barcelona (city) & 0.29 & 0.25 & 0.00 \\
\hline Region: Barcelons (county) & 0.22 & 0.22 & 0.03 \\
\hline Region: Rest of BCN (province) & 0.22 & 0.22 & 0.00 \\
\hline Region: Girona & 0.09 & 0.10 & 0.00 \\
\hline Region: Lleida & 0.07 & 0.08 & 0.00 \\
\hline Region: Tarragona & 0.07 & 0.08 & 0.00 \\
\hline Region: Terres de l'Ebre & 0.04 & 0.04 & 0.00 \\
\hline Marital Status: Married & 0.35 & 0.39 & 0.00 \\
\hline Marital Status: Single & 0.08 & 0.08 & 0.67 \\
\hline Marital Status: Widow & 0.41 & 0.46 & 0.00 \\
\hline Marital Status: Other & 0.16 & 0.07 & 0.00 \\
\hline
\end{tabular}

Note: The 7 regions included corresponds to the 7 "geographical units" used by Social Services Department for organizational purposes. 
Table A3: Medical Diagnosis Groups equivalence to International Classification of Disease 9 (ICD9)

\begin{tabular}{ll}
\hline \hline Name & International Classification of Disease -9 \\
\hline DG: Neurological & Disease of nervous system \\
DG: Circulatory & Disease of circulatory system \\
DG: Digestive & Disease of digestive system \\
DG: Muskuloskeletal & Disease of muskuloskeletal system and connective tissue \\
DG: Endocrino-metabolic & Endocrine, nutritional and metabolic diseases \\
DG: Eye & Disease of Eye \\
DG: Ear & Disease of Ear \\
DG: Respiratory & Disease of respiratory system \\
DG: Genitourinary & Disease of genitourinary system \\
DG: Mental & Mental or Behavioral disorders \\
DG: Malformations & Malformations, deformations and chromosomal abnormalities \\
DG: Cancer & Neoplasms \\
DG: Infectious & Infectious and parasitic diseases \\
DG: Dermatological & Disease of the skin and subcutaneos tissues \\
\hline \hline
\end{tabular}


Table A.4a: Descriptive Statistics, 2011

\begin{tabular}{|c|c|c|c|c|}
\hline & (1) & $(2)$ & (3) & (4) \\
\hline & Sample & Informal Care & Nursing Home & Other \\
\hline \multicolumn{5}{|l|}{ Need Variables } \\
\hline Score & 66.17 & 64.73 & 71.29 & 66.16 \\
\hline Age & 80.47 & 80.00 & 81.42 & 80.92 \\
\hline Gender (female) & 0.69 & 0.67 & 0.72 & 0.71 \\
\hline Physical Disability & 0.14 & 0.16 & 0.07 & 0.16 \\
\hline Intellectual Disability & 0.03 & 0.03 & 0.06 & 0.03 \\
\hline DG: Neurological & 0.42 & 0.40 & 0.48 & 0.44 \\
\hline DG: Circulatory & 0.47 & 0.48 & 0.45 & 0.48 \\
\hline DG: Digestive & 0.02 & 0.02 & 0.02 & 0.02 \\
\hline DG: Muskuloskeletal & 0.42 & 0.42 & 0.39 & 0.45 \\
\hline DG: Endocrino-metabolic & 0.40 & 0.41 & 0.39 & 0.38 \\
\hline DG: Eye & 0.09 & 0.09 & 0.08 & 0.10 \\
\hline DG: Ear & 0.00 & 0.00 & 0.00 & 0.01 \\
\hline DG: Respiratory & 0.20 & 0.21 & 0.18 & 0.19 \\
\hline DG: Genitourinary & 0.34 & 0.34 & 0.32 & 0.34 \\
\hline DG: Mental & 0.28 & 0.28 & 0.33 & 0.27 \\
\hline DG: Development & 0.00 & 0.00 & 0.00 & 0.00 \\
\hline DG: Malformations & 0.00 & 0.00 & 0.01 & 0.00 \\
\hline DG: Cancer & 0.13 & 0.14 & 0.12 & 0.12 \\
\hline DG: Hematological & 0.00 & 0.00 & 0.00 & 0.00 \\
\hline DG: Infectious & 0.01 & 0.01 & 0.01 & 0.01 \\
\hline DG: Dermatological & 0.00 & 0.00 & 0.00 & 0.00 \\
\hline \multicolumn{5}{|l|}{ Non-need Variables } \\
\hline Annual Income & $10,695.25$ & $10,765.16$ & $10,463.39$ & $10,732.85$ \\
\hline Region: Barcelona (city) & 0.26 & 0.23 & 0.21 & 0.36 \\
\hline Region: Barcelonès (county) & 0.22 & 0.21 & 0.27 & 0.23 \\
\hline Region: Rest of BCN (province) & 0.23 & 0.24 & 0.21 & 0.23 \\
\hline Region: Girona & 0.09 & 0.10 & 0.10 & 0.07 \\
\hline Region: Lleida & 0.08 & 0.08 & 0.10 & 0.04 \\
\hline Region: Tarragona & 0.07 & 0.08 & 0.08 & 0.05 \\
\hline Region: Terres de l'Ebre & 0.04 & 0.06 & 0.03 & 0.02 \\
\hline Marital Status: Married & 0.37 & 0.43 & 0.17 & 0.39 \\
\hline Marital Status: Widow & 0.49 & 0.47 & 0.57 & 0.48 \\
\hline Marital Status: Single & 0.09 & 0.06 & 0.20 & 0.08 \\
\hline Marital Status: Other & 0.05 & 0.05 & 0.07 & 0.05 \\
\hline
\end{tabular}

Notes: Other category accounts for Day Care Centre, Home Care, Teleassistance and Medical Nursing Home (all together, they represent less than $28 \%$ ). The 7 regions included corresponds to the 7 'geographical units' used by Social Services Department for organizational purposes. 
Table A.4b: Descriptive Statistics, 2012

\begin{tabular}{|c|c|c|c|c|}
\hline & (1) & $(2)$ & (3) & (4) \\
\hline & Sample & Informal Care & Nursing Home & Other \\
\hline \multicolumn{5}{|l|}{ Need Variables } \\
\hline Score & 65.51 & 63.62 & 72.29 & 64.85 \\
\hline Age & 80.40 & 79.94 & 81.63 & 80.64 \\
\hline Gender (female) & 0.68 & 0.66 & 0.73 & 0.71 \\
\hline Physical Disability & 0.16 & 0.18 & 0.08 & 0.17 \\
\hline Intellectual Disability & 0.04 & 0.03 & 0.06 & 0.03 \\
\hline DG: Neurological & 0.43 & 0.40 & 0.50 & 0.44 \\
\hline DG: Circulatory & 0.47 & 0.48 & 0.44 & 0.48 \\
\hline DG: Digestive & 0.02 & 0.02 & 0.02 & 0.02 \\
\hline DG: Muskuloskeletal & 0.42 & 0.42 & 0.40 & 0.45 \\
\hline DG: Endocrino-metabolic & 0.40 & 0.41 & 0.38 & 0.39 \\
\hline DG: Eye & 0.09 & 0.09 & 0.08 & 0.10 \\
\hline DG: Ear & 0.00 & 0.00 & 0.00 & 0.01 \\
\hline DG: Respiratory & 0.20 & 0.21 & 0.17 & 0.19 \\
\hline DG: Genitourinary & 0.35 & 0.36 & 0.35 & 0.34 \\
\hline DG: Mental & 0.28 & 0.27 & 0.33 & 0.27 \\
\hline DG: Development & 0.00 & 0.00 & 0.00 & 0.00 \\
\hline DG: Malformations & 0.00 & 0.00 & 0.00 & 0.00 \\
\hline DG: Cancer & 0.14 & 0.15 & 0.12 & 0.13 \\
\hline DG: Hematological & 0.00 & 0.00 & 0.00 & 0.00 \\
\hline DG: Infectious & 0.01 & 0.01 & 0.01 & 0.01 \\
\hline DG: Dermatological & 0.00 & 0.00 & 0.00 & 0.00 \\
\hline \multicolumn{5}{|l|}{ Non-need Variables } \\
\hline Annual Income & $10,705.72$ & $10,795.04$ & $10,632.57$ & $10,569.33$ \\
\hline Region: Barcelona (city) & 0.26 & 0.23 & 0.22 & 0.37 \\
\hline Region: Barcelonès (county) & 0.22 & 0.21 & 0.27 & 0.22 \\
\hline Region: Rest of BCN (province) & 0.22 & 0.23 & 0.21 & 0.22 \\
\hline Region: Girona & 0.10 & 0.11 & 0.09 & 0.07 \\
\hline Region: Lleida & 0.08 & 0.08 & 0.10 & 0.05 \\
\hline Region: Tarragona & 0.07 & 0.08 & 0.08 & 0.05 \\
\hline Region: Terres de l'Ebre & 0.04 & 0.06 & 0.03 & 0.02 \\
\hline Marital Status: Married & 0.38 & 0.44 & 0.19 & 0.40 \\
\hline Marital Status: Widow & 0.47 & 0.45 & 0.56 & 0.46 \\
\hline Marital Status: Single & 0.09 & 0.06 & 0.18 & 0.08 \\
\hline Marital Status: Other & 0.06 & 0.05 & 0.07 & 0.06 \\
\hline
\end{tabular}

Notes: Other category accounts for Day Care Centre, Home Care, Teleassistance and Medical Nursing Home (all together, they represent less than 28\%). The 7 regions included corresponds to the 7 'geographical units' used by Social Services Department for organizational purposes. 
Table A.4c: Descriptive Statistics, 2013

\begin{tabular}{|c|c|c|c|c|}
\hline & (1) & $(2)$ & (3) & (4) \\
\hline & Sample & Informal Care & Nursing Home & Other \\
\hline \multicolumn{5}{|l|}{ Need Variables } \\
\hline Score & 65.07 & 63.17 & 72.01 & 63.07 \\
\hline Age & 80.23 & 79.69 & 81.73 & 80.18 \\
\hline Gender (female) & 0.69 & 0.66 & 0.73 & 0.71 \\
\hline Physical Disability & 0.18 & 0.20 & 0.10 & 0.20 \\
\hline Intellectual Disability & 0.04 & 0.03 & 0.06 & 0.04 \\
\hline DG: Neurological & 0.47 & 0.44 & 0.55 & 0.46 \\
\hline DG: Circulatory & 0.47 & 0.47 & 0.43 & 0.48 \\
\hline DG: Digestive & 0.02 & 0.02 & 0.02 & 0.02 \\
\hline DG: Muskuloskeletal & 0.45 & 0.45 & 0.42 & 0.47 \\
\hline DG: Endocrino-metabolic & 0.38 & 0.39 & 0.36 & 0.38 \\
\hline DG: Eye & 0.10 & 0.10 & 0.09 & 0.10 \\
\hline DG: Ear & 0.01 & 0.01 & 0.01 & 0.01 \\
\hline DG: Respiratory & 0.19 & 0.20 & 0.17 & 0.19 \\
\hline DG: Genitourinary & 0.34 & 0.34 & 0.33 & 0.33 \\
\hline DG: Mental & 0.28 & 0.27 & 0.31 & 0.28 \\
\hline DG: Development & 0.00 & 0.00 & 0.00 & 0.00 \\
\hline DG: Malformations & 0.00 & 0.00 & 0.00 & 0.00 \\
\hline DG: Cancer & 0.13 & 0.13 & 0.12 & 0.12 \\
\hline DG: Hematological & 0.00 & 0.00 & 0.00 & 0.01 \\
\hline DG: Infectious & 0.01 & 0.01 & 0.01 & 0.01 \\
\hline DG: Dermatological & 0.00 & 0.00 & 0.00 & 0.00 \\
\hline \multicolumn{5}{|l|}{ Non-need Variables } \\
\hline Annual Income & $10,730.35$ & $10,851.38$ & $10,718.26$ & $10,471.95$ \\
\hline Region: Barcelona (city) & 0.27 & 0.23 & 0.23 & 0.38 \\
\hline Region: Barcelonès (county) & 0.22 & 0.21 & 0.27 & 0.21 \\
\hline Region: Rest of BCN (province) & 0.22 & 0.23 & 0.20 & 0.22 \\
\hline Region: Girona & 0.10 & 0.11 & 0.09 & 0.07 \\
\hline Region: Lleida & 0.08 & 0.08 & 0.10 & 0.05 \\
\hline Region: Tarragona & 0.08 & 0.08 & 0.08 & 0.06 \\
\hline Region: Terres de l'Ebre & 0.04 & 0.06 & 0.03 & 0.02 \\
\hline Marital Status: Married & 0.39 & 0.45 & 0.21 & 0.42 \\
\hline Marital Status: Widow & 0.47 & 0.44 & 0.55 & 0.45 \\
\hline Marital Status: Single & 0.09 & 0.06 & 0.17 & 0.08 \\
\hline Marital Status: Other & 0.06 & 0.05 & 0.07 & 0.06 \\
\hline
\end{tabular}

Notes: Other category accounts for Day Care Centre, Home Care, Teleassistance and Medical Nursing Home (all together, they represent less than $28 \%$ ). The 7 regions included corresponds to the 7 'geographical units' used by Social Services Department for organizational purposes. 
Table A.4d: Descriptive Statistics, 2014

\begin{tabular}{|c|c|c|c|c|}
\hline & (1) & $(2)$ & (3) & (4) \\
\hline & Sample & Informal Care & Nursing Home & Other \\
\hline \multicolumn{5}{|l|}{ Need Variables } \\
\hline Score & 64.67 & 62.63 & 71.52 & 62.35 \\
\hline Age & 79.87 & 79.20 & 81.47 & 79.80 \\
\hline Gender (female) & 0.69 & 0.67 & 0.74 & 0.71 \\
\hline Physical Disability & 0.20 & 0.23 & 0.12 & 0.22 \\
\hline Intellectual Disability & 0.04 & 0.03 & 0.06 & 0.04 \\
\hline DG: Neurological & 0.50 & 0.47 & 0.58 & 0.50 \\
\hline DG: Circulatory & 0.46 & 0.47 & 0.42 & 0.47 \\
\hline DG: Digestive & 0.02 & 0.03 & 0.02 & 0.02 \\
\hline DG: Muskuloskeletal & 0.47 & 0.47 & 0.45 & 0.49 \\
\hline DG: Endocrino-metabolic & 0.37 & 0.38 & 0.34 & 0.36 \\
\hline DG: Eye & 0.11 & 0.11 & 0.10 & 0.11 \\
\hline DG: Ear & 0.02 & 0.02 & 0.02 & 0.02 \\
\hline DG: Respiratory & 0.18 & 0.19 & 0.16 & 0.18 \\
\hline DG: Genitourinary & 0.32 & 0.32 & 0.32 & 0.30 \\
\hline DG: Mental & 0.28 & 0.26 & 0.31 & 0.28 \\
\hline DG: Development & 0.01 & 0.01 & 0.01 & 0.01 \\
\hline DG: Malformations & 0.00 & 0.00 & 0.01 & 0.00 \\
\hline DG: Cancer & 0.12 & 0.13 & 0.11 & 0.11 \\
\hline DG: Hematological & 0.01 & 0.01 & 0.01 & 0.01 \\
\hline DG: Infectious & 0.01 & 0.01 & 0.01 & 0.01 \\
\hline DG: Dermatological & 0.00 & 0.00 & 0.00 & 0.00 \\
\hline \multicolumn{5}{|l|}{ Non-need Variables } \\
\hline Annual Income & $10,766.19$ & $10,940.33$ & $10,656.72$ & $10,549.62$ \\
\hline Region: Barcelona (city) & 0.26 & 0.22 & 0.24 & 0.37 \\
\hline Region: Barcelonès (county) & 0.22 & 0.21 & 0.26 & 0.22 \\
\hline Region: Rest of BCN (province) & 0.22 & 0.24 & 0.20 & 0.22 \\
\hline Region: Girona & 0.09 & 0.11 & 0.09 & 0.07 \\
\hline Region: Lleida & 0.08 & 0.09 & 0.09 & 0.05 \\
\hline Region: Tarragona & 0.07 & 0.08 & 0.08 & 0.06 \\
\hline Region: Terres de l'Ebre & 0.04 & 0.06 & 0.03 & 0.02 \\
\hline Marital Status: Married & 0.39 & 0.46 & 0.22 & 0.43 \\
\hline Marital Status: Widow & 0.46 & 0.43 & 0.54 & 0.43 \\
\hline Marital Status: Single & 0.09 & 0.06 & 0.17 & 0.07 \\
\hline Marital Status: Other & 0.06 & 0.05 & 0.07 & 0.06 \\
\hline
\end{tabular}

Notes: Other category accounts for Day Care Centre, Home Care, Teleassistance and Medical Nursing Home (all together, they represent less than $28 \%$ ). The 7 regions included corresponds to the 7 'geographical units' used by Social Services Department for organizational purposes. 
Table A5: Linear Probability Model - Choice of LTC Benefit

\begin{tabular}{|c|c|c|c|c|c|c|c|c|c|}
\hline & $(1)$ & $(2)$ & $(3)$ & $(4)$ & $(5)$ & $(6)$ & $(7)$ & $(8)$ & $(9)$ \\
\hline & $\mathrm{HC}$ & DCC & TA & IC & $\mathrm{NH}$ & $\mathrm{MNH}$ & In-kind & NHS & NHV \\
\hline \multicolumn{10}{|l|}{ Need variables } \\
\hline Score & $\begin{array}{l}-0.0010^{* * *} \\
(<0.001)\end{array}$ & $\begin{array}{l}-0.0002^{* * *} \\
(<0.001)\end{array}$ & $\begin{array}{l}-0.0016^{* * *} \\
(<0.001)\end{array}$ & $\begin{array}{l}-0.0036^{* * *} \\
(<0.001)\end{array}$ & $\begin{array}{l}0.0059^{* * *} \\
(<0.001)\end{array}$ & $\begin{array}{l}0.0007^{* * *} \\
(<0.001)\end{array}$ & $\begin{array}{l}0.0013^{* * *} \\
(<0.001)\end{array}$ & $\begin{array}{l}0.0033^{* * *} \\
(<0.001)\end{array}$ & $\begin{array}{l}0.0026^{* * *} \\
(<0.001)\end{array}$ \\
\hline Age & $\begin{array}{l}0.0003^{* * *} \\
(<0.001)\end{array}$ & $\begin{array}{l}-0.0010^{* * *} \\
(<0.001)\end{array}$ & $\begin{array}{l}0.0020^{* * *} \\
(<0.001)\end{array}$ & $\begin{array}{l}-0.0032^{* * *} \\
(<0.001)\end{array}$ & $\begin{array}{l}0.0031^{* * *} \\
(<0.001)\end{array}$ & $\begin{array}{l}-0.0006^{* * *} \\
(<0.001)\end{array}$ & $\begin{array}{l}0.0011^{* * *} \\
(<0.001)\end{array}$ & $\begin{array}{l}0.0008^{* * *} \\
(<0.001)\end{array}$ & $\begin{array}{l}0.0023^{* * *} \\
(<0.001)\end{array}$ \\
\hline Female & $\begin{array}{l}0.0230^{* * *} \\
(0.001)\end{array}$ & $\begin{array}{l}0.0042^{* * *} \\
(0.001)\end{array}$ & $\begin{array}{l}0.0155^{* * *} \\
(0.001)\end{array}$ & $\begin{array}{l}-0.0253^{* * *} \\
(0.002)\end{array}$ & $\begin{array}{l}-0.0001 \\
(0.001)\end{array}$ & $\begin{array}{l}-0.0041^{* * *} \\
(<0.001)\end{array}$ & $\begin{array}{l}0.0217^{* * * *} \\
(0.002)\end{array}$ & $\begin{array}{l}-0.0097^{* * *} \\
(0.001)\end{array}$ & $\begin{array}{l}0.0097^{* * *} \\
(0.001)\end{array}$ \\
\hline Physical Disability & $\begin{array}{l}0.0181^{* * *} \\
(0.001)\end{array}$ & $\begin{array}{l}-0.0076^{* * *} \\
(0.001)\end{array}$ & $\begin{array}{l}0.0068^{* * *} \\
(0.001)\end{array}$ & $\begin{array}{l}0.0417^{* * *} \\
(0.002)\end{array}$ & $\begin{array}{l}-0.0534^{* * *} \\
(0.002)\end{array}$ & $\begin{array}{l}-0.0080^{* * *} \\
(0.001)\end{array}$ & $\begin{array}{l}-0.0239^{* * * *} \\
(0.002)\end{array}$ & $\begin{array}{l}-0.0365^{* * *} \\
(0.001)\end{array}$ & $\begin{array}{l}-0.0169^{* * *} \\
(0.001)\end{array}$ \\
\hline Intellectual Disability & $\begin{array}{l}-0.0173^{* * *} \\
(0.002)\end{array}$ & $\begin{array}{l}0.0549^{* * *} \\
(0.002)\end{array}$ & $\begin{array}{l}-0.0222^{* * *} \\
(0.002)\end{array}$ & $\begin{array}{l}-0.0541^{* * *} \\
(0.004)\end{array}$ & $\begin{array}{l}0.0459^{* * *} \\
(0.003)\end{array}$ & $\begin{array}{l}-0.0144^{* * *} \\
(0.001)\end{array}$ & $\begin{array}{l}0.0653^{* * *} \\
(0.004)\end{array}$ & $\begin{array}{l}0.0642^{* * *} \\
(0.003)\end{array}$ & $\begin{array}{l}-0.0183^{* * *} \\
(0.002)\end{array}$ \\
\hline DG: Neurological & $\begin{array}{l}-0.0158^{* * *} \\
(0.001)\end{array}$ & $\begin{array}{l}0.0362^{* * *} \\
(0.001)\end{array}$ & $\begin{array}{l}-0.0131^{* * *} \\
(0.001)\end{array}$ & $\begin{array}{l}-0.0257^{* * *} \\
(0.001)\end{array}$ & $\begin{array}{l}0.0289^{* * *} \\
(0.001)\end{array}$ & $\begin{array}{l}-0.0034^{* * *} \\
(<0.001)\end{array}$ & $\begin{array}{l}0.0162^{* * *} \\
(0.001)\end{array}$ & $\begin{array}{l}0.0185^{* * *} \\
(0.001)\end{array}$ & $\begin{array}{l}0.0105^{\text {*** }} \\
(0.001)\end{array}$ \\
\hline DG: Circulatory & $\begin{array}{l}0.0057^{* * *} \\
(0.001)\end{array}$ & $\begin{array}{l}-0.0023^{* * *} \\
(0.001)\end{array}$ & $\begin{array}{l}0.0062^{* * *} \\
(0.001)\end{array}$ & $\begin{array}{l}0.0153^{* * *} \\
(0.001)\end{array}$ & $\begin{array}{l}-0.0225^{* * *} \\
(0.001)\end{array}$ & $\begin{array}{l}-0.0020^{* * *} \\
(<0.001)\end{array}$ & $\begin{array}{l}-0.0076^{* * *} \\
(0.001)\end{array}$ & $\begin{array}{l}-0.0153^{* * *} \\
(0.001)\end{array}$ & $\begin{array}{l}-0.0072^{\text {**** }} \\
(0.001)\end{array}$ \\
\hline DG: Digestive & $\begin{array}{l}0.0080^{* * *} \\
(0.003)\end{array}$ & $\begin{array}{l}-0.0085^{* * *} \\
(0.002)\end{array}$ & $\begin{array}{l}-0.0099^{* * *} \\
(0.003)\end{array}$ & $\begin{array}{l}0.0057 \\
(0.005)\end{array}$ & $\begin{array}{l}-0.0020 \\
(0.004)\end{array}$ & $\begin{array}{l}0.0021 \\
(0.001)\end{array}$ & $\begin{array}{l}-0.0014 \\
(0.005)\end{array}$ & $\begin{array}{l}0.0057^{*} \\
(0.003)\end{array}$ & $\begin{array}{l}-0.0077^{* * *} \\
(0.003)\end{array}$ \\
\hline DG: Muskuloskeletal & $\begin{array}{l}0.0105^{* * *} \\
(0.001)\end{array}$ & $\begin{array}{l}-0.0054^{* * *} \\
(0.001)\end{array}$ & $\begin{array}{l}0.0109^{* * *} \\
(0.001)\end{array}$ & $\begin{array}{l}0.0032^{* *} \\
(0.001)\end{array}$ & $\begin{array}{l}-0.0098^{* * *} \\
(0.001)\end{array}$ & $\begin{array}{l}-0.0056^{* * *} \\
(<0.001)\end{array}$ & $\begin{array}{c}-0.0002 \\
(0.001)\end{array}$ & $\begin{array}{l}-0.0078^{* * *} \\
(0.001)\end{array}$ & $\begin{array}{l}-0.0020^{* *} \\
(0.001)\end{array}$ \\
\hline DG: Endocrino-metabolic & $\begin{array}{l}0.0002 \\
(0.001)\end{array}$ & $\begin{array}{l}0.0005 \\
(0.001)\end{array}$ & $\begin{array}{l}0.0021^{* *} \\
(0.001)\end{array}$ & $\begin{array}{l}0.0056^{\text {*** }} \\
(0.001)\end{array}$ & $\begin{array}{l}-0.0059^{* * *} \\
(0.001)\end{array}$ & $\begin{array}{l}-0.0016^{* * *} \\
(<0.001)\end{array}$ & $\begin{array}{l}-0.0012 \\
(0.001)\end{array}$ & $\begin{array}{l}-0.0027^{\text {*** }} \\
(0.001)\end{array}$ & $\begin{array}{l}-0.0031^{* * *} \\
(0.001)\end{array}$ \\
\hline DG: Eye & $\begin{array}{l}0.0086^{* * *} \\
(0.001)\end{array}$ & $\begin{array}{l}-0.0055^{* * *} \\
(0.001)\end{array}$ & $\begin{array}{l}0.0066^{* * *} \\
(0.001)\end{array}$ & $\begin{array}{l}0.0184^{* * *} \\
(0.002)\end{array}$ & $\begin{array}{l}-0.0223^{* * *} \\
(0.002)\end{array}$ & $\begin{array}{l}-0.0055^{* * *} \\
(0.001)\end{array}$ & $\begin{array}{l}-0.0100^{* * *} \\
(0.002)\end{array}$ & $\begin{array}{l}-0.0128^{* * *} \\
(0.002)\end{array}$ & $\begin{array}{l}-0.0095^{* * *} \\
(0.001)\end{array}$ \\
\hline DG: Ear & $\begin{array}{l}0.0010 \\
(0.004)\end{array}$ & $\begin{array}{l}0.0022 \\
(0.003)\end{array}$ & $\begin{array}{l}0.0026 \\
(0.004)\end{array}$ & $\begin{array}{l}0.0014 \\
(0.006)\end{array}$ & $\begin{array}{l}-0.0015 \\
(0.005)\end{array}$ & $\begin{array}{l}-0.0081^{* * *} \\
(0.002)\end{array}$ & $\begin{array}{l}-0.0033 \\
(0.006)\end{array}$ & $\begin{array}{l}-0.0006 \\
(0.004)\end{array}$ & $\begin{array}{l}-0.0009 \\
(0.003)\end{array}$ \\
\hline DG: Respiratory & $\begin{array}{l}0.0027^{* *} \\
(0.001)\end{array}$ & $\begin{array}{l}-0.0044^{* * *} \\
(0.001)\end{array}$ & $\begin{array}{l}0.0032^{* * *} \\
(0.001)\end{array}$ & $\begin{array}{l}0.0165^{* * *} \\
(0.002)\end{array}$ & $\begin{array}{l}-0.0162^{* * *} \\
(0.001)\end{array}$ & $\begin{array}{l}-0.0020^{* * *} \\
(<0.001)\end{array}$ & $\begin{array}{l}-0.0097^{* * *} \\
(0.002)\end{array}$ & $\begin{array}{l}-0.0092^{* * * *} \\
(0.001)\end{array}$ & $\begin{array}{l}-0.0070^{* * *} \\
(0.001)\end{array}$ \\
\hline DG: Genitourinary & $\begin{array}{l}0.0031^{* * *} \\
(0.001)\end{array}$ & $\begin{array}{l}-0.0012^{*} \\
(0.001)\end{array}$ & $\begin{array}{l}0.0007 \\
(0.001)\end{array}$ & $\begin{array}{l}0.0126^{* * *} \\
(0.001)\end{array}$ & $\begin{array}{l}-0.0111^{* * *} \\
(0.001)\end{array}$ & $\begin{array}{l}-0.0035^{* * *} \\
(<0.001)\end{array}$ & $\begin{array}{l}-0.0092^{* * *} \\
(0.001)\end{array}$ & $\begin{array}{l}-0.0079^{* * *} \\
(0.001)\end{array}$ & $\begin{array}{l}-0.0032^{\text {*** }} \\
(0.001)\end{array}$ \\
\hline DG: Mental & $\begin{array}{l}0.0001 \\
(0.001)\end{array}$ & $\begin{array}{l}0.0010 \\
(0.001)\end{array}$ & $\begin{array}{l}-0.0017^{*} \\
(0.001)\end{array}$ & $\begin{array}{l}-0.0262^{* * *} \\
(0.002)\end{array}$ & $\begin{array}{l}0.0303^{* * *} \\
(0.001)\end{array}$ & $\begin{array}{l}-0.0013^{* * *} \\
(<0.001)\end{array}$ & $\begin{array}{l}0.0240^{* * *} \\
(0.002)\end{array}$ & $\begin{array}{l}0.0253^{* * *} \\
(0.001)\end{array}$ & $\begin{array}{l}0.0050^{* * *} \\
(0.001)\end{array}$ \\
\hline DG: Development & $\begin{array}{l}0.0350^{* * *} \\
(0.007)\end{array}$ & $\begin{array}{l}-0.0039 \\
(0.005)\end{array}$ & $\begin{array}{l}-0.0189^{* * *} \\
(0.007)\end{array}$ & $\begin{array}{l}-0.0065 \\
(0.011)\end{array}$ & $\begin{array}{c}-0.0060 \\
(0.009)\end{array}$ & $\begin{array}{l}0.0064^{* *} \\
(0.003)\end{array}$ & $\begin{array}{l}0.0286^{* * *} \\
(0.011)\end{array}$ & $\begin{array}{l}0.0132^{*} \\
(0.008)\end{array}$ & $\begin{array}{l}-0.0191^{* * *} \\
(0.006)\end{array}$ \\
\hline DG: Malformations & $\begin{array}{l}-0.0224^{* * *} \\
(0.007)\end{array}$ & $\begin{array}{l}0.0439^{* * *} \\
(0.005)\end{array}$ & $\begin{array}{l}0.0084 \\
(0.007)\end{array}$ & $\begin{array}{c}-0.0006 \\
(0.011)\end{array}$ & $\begin{array}{l}-0.0187^{* *} \\
(0.009)\end{array}$ & $\begin{array}{l}-0.0219^{* * *} \\
(0.003)\end{array}$ & $\begin{array}{l}0.0222^{* *} \\
(0.011)\end{array}$ & $\begin{array}{l}0.0113 \\
(0.008)\end{array}$ & $\begin{array}{l}-0.0301^{* * *} \\
(0.006)\end{array}$ \\
\hline DG: Cancer & $\begin{array}{l}-0.0055^{* * *} \\
(0.001)\end{array}$ & $\begin{array}{l}-0.0036^{* * *} \\
(0.001)\end{array}$ & $\begin{array}{c}-0.0006 \\
(0.001)\end{array}$ & $\begin{array}{l}0.0157^{* * *} \\
(0.002)\end{array}$ & $\begin{array}{l}-0.0075^{* * *} \\
(0.002)\end{array}$ & $\begin{array}{l}0.0001 \\
(0.001)\end{array}$ & $\begin{array}{l}-0.0167^{* * *} \\
(0.002)\end{array}$ & $\begin{array}{l}-0.0083^{* * *} \\
(0.001)\end{array}$ & $\begin{array}{l}0.0008 \\
(0.001)\end{array}$ \\
\hline DG: Hematological & $\begin{array}{l}-0.0015 \\
(0.006)\end{array}$ & $\begin{array}{l}-0.0066 \\
(0.004)\end{array}$ & $\begin{array}{l}-0.0058 \\
(0.006)\end{array}$ & $\begin{array}{l}0.0056 \\
(0.009)\end{array}$ & $\begin{array}{l}0.0124 \\
(0.008)\end{array}$ & $\begin{array}{l}0.0035 \\
(0.003)\end{array}$ & $\begin{array}{l}0.0039 \\
(0.009)\end{array}$ & $\begin{array}{l}0.0119^{*} \\
(0.007)\end{array}$ & $\begin{array}{l}0.0005 \\
(0.005)\end{array}$ \\
\hline DG: Infectious & $\begin{array}{l}0.0166^{* * *} \\
(0.004)\end{array}$ & $\begin{array}{r}-0.0017 \\
(0.003)\end{array}$ & $\begin{array}{l}0.0124^{* * *} \\
(0.004)\end{array}$ & $\begin{array}{l}0.0118^{*} \\
(0.007)\end{array}$ & $\begin{array}{l}-0.0236^{* * *} \\
(0.006)\end{array}$ & $\begin{array}{l}0.0016 \\
(0.002)\end{array}$ & $\begin{array}{l}0.0059 \\
(0.007)\end{array}$ & $\begin{array}{l}-0.0156^{* * *} \\
(0.005)\end{array}$ & $\begin{array}{l}-0.0081^{* *} \\
(0.004)\end{array}$ \\
\hline DG: Dermatological & $\begin{array}{c}-0.0306^{*} \\
(0.016)\end{array}$ & $\begin{array}{l}-0.0256^{* *} \\
(0.011)\end{array}$ & $\begin{array}{c}-0.0024 \\
(0.015)\end{array}$ & $\begin{array}{l}0.0215 \\
(0.024)\end{array}$ & $\begin{array}{l}-0.0282 \\
(0.020)\end{array}$ & $\begin{array}{l}0.0408^{* * *} \\
(0.007)\end{array}$ & $\begin{array}{c}-0.0133 \\
(0.024)\end{array}$ & $\begin{array}{l}-0.0205 \\
(0.017)\end{array}$ & $\begin{array}{r}-0.0077 \\
(0.014)\end{array}$ \\
\hline \multicolumn{10}{|l|}{ Non-need Variables } \\
\hline Anual Personal Income (ln) & $\begin{array}{l}-0.0093^{* * *} \\
(<0.001)\end{array}$ & $\begin{array}{l}0.0014^{* * *} \\
(<0.001)\end{array}$ & $\begin{array}{l}0.0005 \\
(<0.001)\end{array}$ & $\begin{array}{l}0.0137^{* * *} \\
(0.001)\end{array}$ & $\begin{array}{l}-0.0046^{* * *} \\
(0.001)\end{array}$ & $\begin{array}{l}-0.0023^{* * *} \\
(<0.001)\end{array}$ & $\begin{array}{l}-0.0270^{* * *} \\
(0.001)\end{array}$ & $\begin{array}{l}-0.0174^{* * *} \\
(0.001)\end{array}$ & $\begin{array}{l}0.0128^{* * *} \\
(<0.001)\end{array}$ \\
\hline Region: Barcelona City & $\begin{array}{l}0.0964^{* * * *} \\
(0.002)\end{array}$ & $\begin{array}{l}-0.0137^{* * *} \\
(0.001)\end{array}$ & $\begin{array}{l}0.1237^{* * *} \\
(0.002)\end{array}$ & $\begin{array}{l}-0.1045^{* * *} \\
(0.003)\end{array}$ & $\begin{array}{l}-0.0668^{* * *} \\
(0.002)\end{array}$ & $\begin{array}{l}-0.0097^{* * *} \\
(0.001)\end{array}$ & $\begin{array}{l}0.0832^{* * *} \\
(0.003)\end{array}$ & $\begin{array}{l}-0.0976^{* * *} \\
(0.002)\end{array}$ & $\begin{array}{l}0.0307^{* * *} \\
(0.002)\end{array}$ \\
\hline Region: Barcelona County & $\begin{array}{l}0.0317^{* * *} \\
(0.002)\end{array}$ & $\begin{array}{l}-0.0078^{* * *} \\
(0.001)\end{array}$ & $\begin{array}{l}0.0704^{* * *} \\
(0.002)\end{array}$ & $\begin{array}{l}-0.0698^{* * *} \\
(0.003)\end{array}$ & $\begin{array}{l}0.0121^{* * *} \\
(0.002)\end{array}$ & $\begin{array}{l}-0.0081^{* * *} \\
(0.001)\end{array}$ & $\begin{array}{l}0.0275^{* * *} \\
(0.003)\end{array}$ & $\begin{array}{l}-0.0384^{* * *} \\
(0.002)\end{array}$ & $\begin{array}{l}0.0504^{* * *} \\
(0.002)\end{array}$ \\
\hline Region: Barcelona Province & $\begin{array}{l}0.0478^{* * * *} \\
(0.002)\end{array}$ & $\begin{array}{l}-0.0149^{* * *} \\
(0.001)\end{array}$ & $\begin{array}{l}0.0609^{* * *} \\
(0.002)\end{array}$ & $\begin{array}{l}-0.0147^{* * *} \\
(0.003)\end{array}$ & $\begin{array}{l}-0.0459^{* * *} \\
(0.002)\end{array}$ & $\begin{array}{l}-0.0166^{* * *} \\
(0.001)\end{array}$ & $\begin{array}{l}-0.0096^{* * *} \\
(0.003)\end{array}$ & $\begin{array}{l}-0.0763^{* * * *} \\
(0.002)\end{array}$ & $\begin{array}{l}0.0304^{* * *} \\
(0.002)\end{array}$ \\
\hline Region: Girona & $\begin{array}{l}0.0098^{* * *} \\
(0.002)\end{array}$ & $\begin{array}{l}-0.0139^{* * *} \\
(0.001)\end{array}$ & $\begin{array}{l}0.0202^{\text {*** }} \\
(0.002)\end{array}$ & $\begin{array}{l}0.0389^{* * *} \\
(0.003)\end{array}$ & $\begin{array}{l}-0.0503^{* * *} \\
(0.003)\end{array}$ & $\begin{array}{l}-0.0052^{* * *} \\
(0.001)\end{array}$ & $\begin{array}{l}-0.0503^{* * *} \\
(0.003)\end{array}$ & $\begin{array}{l}-0.0623^{* * *} \\
(0.002)\end{array}$ & $\begin{array}{l}0.0120^{* * *} \\
(0.002)\end{array}$ \\
\hline Region: Lleida & $\begin{array}{l}-0.0125^{* * *} \\
(0.002)\end{array}$ & $\begin{array}{l}-0.0131^{* * * *} \\
(0.002)\end{array}$ & $\begin{array}{l}0.0009 \\
(0.002)\end{array}$ & $\begin{array}{l}0.0242^{* * *} \\
(0.003)\end{array}$ & $\begin{array}{l}0.0004 \\
(0.003)\end{array}$ & $\begin{array}{l}-0.0110^{* * *} \\
(0.001)\end{array}$ & $\begin{array}{l}-0.0420^{* * * *} \\
(0.003)\end{array}$ & $\begin{array}{l}-0.0138^{* * * *} \\
(0.002)\end{array}$ & $\begin{array}{l}0.0142^{* * *} \\
(0.002)\end{array}$ \\
\hline Region: Terres de l'Ebre & $\begin{array}{l}-0.0099^{* * *} \\
(0.003)\end{array}$ & $\begin{array}{l}-0.0077^{* * *} \\
(0.002)\end{array}$ & $\begin{array}{l}-0.0305^{* * *} \\
(0.002)\end{array}$ & $\begin{array}{l}0.1635^{* * *} \\
(0.004)\end{array}$ & $\begin{array}{l}-0.1208^{* * *} \\
(0.003)\end{array}$ & $\begin{array}{l}-0.0155^{* * *} \\
(0.001)\end{array}$ & $\begin{array}{l}-0.1335^{* * *} \\
(0.004)\end{array}$ & $\begin{array}{l}-0.0859^{* * *} \\
(0.003)\end{array}$ & $\begin{array}{l}-0.0349^{* * *} \\
(0.002)\end{array}$ \\
\hline Marital Status: Widow & $\begin{array}{l}-0.0456^{* * *} \\
(0.001)\end{array}$ & $\begin{array}{l}0.0071^{* * *} \\
(0.001)\end{array}$ & $\begin{array}{l}-0.0114^{* * *} \\
(0.001)\end{array}$ & $\begin{array}{l}-0.0830^{* * *} \\
(0.002)\end{array}$ & $\begin{array}{l}0.1215^{* * *} \\
(0.001)\end{array}$ & $\begin{array}{l}0.0044^{* * *} \\
(<0.001)\end{array}$ & $\begin{array}{l}0.0316^{* * *} \\
(0.002)\end{array}$ & $\begin{array}{l}0.0765^{* * *} \\
(0.001)\end{array}$ & $\begin{array}{l}0.0450^{* * *} \\
(0.001)\end{array}$ \\
\hline Marital Status: Single & $\begin{array}{l}-0.0351^{* * *} \\
(0.002)\end{array}$ & $\begin{array}{l}-0.0095^{* * *} \\
(0.001)\end{array}$ & $\begin{array}{l}-0.0307^{* * *} \\
(0.002)\end{array}$ & $\begin{array}{l}-0.2805^{* * *} \\
(0.003)\end{array}$ & $\begin{array}{l}0.3269^{* * *} \\
(0.002)\end{array}$ & $\begin{array}{l}0.0153^{* * *} \\
(0.001)\end{array}$ & $\begin{array}{l}0.1864^{* * *} \\
(0.003)\end{array}$ & $\begin{array}{l}0.2409^{* * *} \\
(0.002)\end{array}$ & $\begin{array}{l}0.0860^{* * *} \\
(0.001)\end{array}$ \\
\hline Marital Status: Other & $\begin{array}{l}-0.0063^{* * *} \\
(0.002)\end{array}$ & $\begin{array}{l}-0.0111^{* * *} \\
(0.001)\end{array}$ & $\begin{array}{l}-0.0163^{* * *} \\
(0.002)\end{array}$ & $\begin{array}{l}-0.1497^{* * *} \\
(0.003)\end{array}$ & $\begin{array}{l}0.1633^{\text {*** }} \\
(0.002)\end{array}$ & $\begin{array}{l}0.0152^{\text {*** }} \\
(0.001)\end{array}$ & $\begin{array}{l}0.1010^{* * *} \\
(0.003)\end{array}$ & $\begin{array}{l}0.1187^{* * *} \\
(0.002)\end{array}$ & $\begin{array}{l}0.0446^{* * *} \\
(0.002)\end{array}$ \\
\hline Observations & & & & & 518,178 & & & & \\
\hline R-squared & 0.027 & 0.014 & 0.042 & 0.081 & 0.132 & 0.016 & 0.044 & 0.092 & 0.055 \\
\hline
\end{tabular}

Notes: dependent variables are: $\mathrm{HC}=$ Home Care; $\mathrm{DCC}=$ Day Care Centre; TA = Tele-assistance; NH=Nursing

Home; $\mathrm{MNH}=$ Medical Nursing Home; NHV=Nursing Home, Voucher and NHS=Nursing Home, In-kind. The reference categories are Married and Tarragona Region. The 7 regions included corresponds to the 7 "geographical units" used by Social Services Department for managerial purpose. Barcelona County includes Barcelona Metropolitan Area excluding Barcelona City and Barcelona Province excludes Barcelona Metropolitan Area including Barcelona city. The specifications include year fixed effect. Standard errors in parentheses.

** indicates $1 \%$ significance, ${ }^{* *} 5 \%$ and $* 10 \%$. 
Table A6: CCI and CHI per Benefit and Year

\begin{tabular}{|c|c|c|c|c|c|c|c|c|c|c|c|c|c|c|c|c|}
\hline & \multicolumn{2}{|c|}{ (1) } & \multicolumn{2}{|l|}{$(2)$} & \multicolumn{2}{|c|}{$(3)$} & \multicolumn{2}{|l|}{$(4)$} & \multicolumn{2}{|l|}{$(5)$} & \multicolumn{2}{|l|}{$(6)$} & \multicolumn{2}{|l|}{ (7) } & \multicolumn{2}{|l|}{$(8)$} \\
\hline & \multicolumn{4}{|c|}{2011} & \multirow{2}{*}{\multicolumn{4}{|c|}{2012}} & \multicolumn{4}{|c|}{2013} & \multicolumn{4}{|c|}{2014} \\
\hline & \multicolumn{2}{|c|}{ CCI } & \multicolumn{2}{|l|}{$\mathrm{CHI}$} & & & & & \multicolumn{2}{|l|}{$\mathrm{CCI}$} & \multicolumn{2}{|l|}{$\mathrm{CHI}$} & \multicolumn{2}{|c|}{$\mathrm{CCI}$} & \multicolumn{2}{|l|}{$\mathrm{CHI}$} \\
\hline Day Care Centre (DCC) & $\begin{array}{r}0.0077 \\
(0.002)\end{array}$ & $* * *$ & $\begin{array}{r}0.0061 \\
(0.002)\end{array}$ & $* * *$ & $\begin{array}{c}0.0032 \\
(0.002)\end{array}$ & $* *$ & $\begin{array}{c}0.0024 \\
(0.002)\end{array}$ & & $\begin{array}{r}0.0015 \\
(0.002)\end{array}$ & & $\begin{array}{r}0.0013 \\
(0.002)\end{array}$ & & $\begin{array}{c}0.0033 \\
(0.002)\end{array}$ & $*$ & $\begin{array}{r}0.0025 \\
(0.002)\end{array}$ & \\
\hline Nursing Home (NH) & $\begin{array}{c}-0.0114 \\
(0.003)\end{array}$ & $* * *$ & $\begin{array}{r}-0.0101 \\
(0.003)\end{array}$ & $* * *$ & $\begin{array}{r}0.0001 \\
(0.003)\end{array}$ & & $\begin{array}{r}-0.0028 \\
(0.003)\end{array}$ & & $\begin{array}{c}0.0064 \\
(0.003)\end{array}$ & $* *$ & $\begin{array}{r}-0.0020 \\
(0.003)\end{array}$ & & $\begin{array}{c}0.0005 \\
(0.003)\end{array}$ & & $\begin{array}{c}-0.0104 \\
(0.003)\end{array}$ & $* * *$ \\
\hline Medical Nursing Home (MNH) & $\begin{array}{c}-0.0059 \\
(0.001)\end{array}$ & $* * *$ & $\begin{array}{r}-0.0075 \\
(0.001)\end{array}$ & $* * *$ & $\begin{array}{r}-0.0045 \\
(0.001)\end{array}$ & $* * *$ & $\begin{array}{r}-0.0057 \\
(0.001)\end{array}$ & $* * *$ & $\begin{array}{r}-0.0038 \\
(0.001)\end{array}$ & $* * *$ & $\begin{array}{r}-0.0055 \\
(0.001)\end{array}$ & $* * *$ & $\begin{array}{r}-0.0028 \\
(0.001)\end{array}$ & $* * *$ & $\begin{array}{r}-0.0049 \\
(0.001)\end{array}$ & $* * *$ \\
\hline Tele-assistance ( $\mathrm{T})$ & $\begin{array}{c}0.0284 \\
(0.003)\end{array}$ & $* * *$ & $\begin{array}{r}0.0307 \\
(0.003)\end{array}$ & $* * *$ & $\begin{array}{c}0.0224 \\
(0.002)\end{array}$ & $* * *$ & $\begin{array}{c}0.0229 \\
(0.002)\end{array}$ & $* * *$ & $\begin{array}{r}0.0157 \\
(0.002)\end{array}$ & $* * *$ & $\begin{array}{c}0.0174 \\
(0.002)\end{array}$ & $* * *$ & $\begin{array}{r}0.0137 \\
(0.002)\end{array}$ & $* * *$ & $\begin{array}{c}0.0162 \\
(0.002)\end{array}$ & $* * *$ \\
\hline Informal Care (IC) & $\begin{array}{c}0.0024 \\
(0.004)\end{array}$ & & $\begin{array}{c}0.0023 \\
(0.004)\end{array}$ & & $\begin{array}{r}0.0105 \\
(0.004)\end{array}$ & $* * *$ & $\begin{array}{r}0.0128 \\
(0.004)\end{array}$ & $* * *$ & $\begin{array}{r}0.0160 \\
(0.003)\end{array}$ & $* * *$ & $\begin{array}{r}0.0188 \\
(0.003)\end{array}$ & $* * *$ & $\begin{array}{r}0.0211 \\
(0.004)\end{array}$ & $* * *$ & $\begin{array}{r}0.0266 \\
(0.004)\end{array}$ & $* * *$ \\
\hline Home Care (HC) & $\begin{array}{r}-0.0146 \\
(0.003)\end{array}$ & $* * *$ & $\begin{array}{r}-0.0148 \\
(0.003)\end{array}$ & $* * *$ & $\begin{array}{r}-0.0286 \\
(0.002)\end{array}$ & $* * *$ & $\begin{array}{r}-0.0272 \\
(0.002)\end{array}$ & $* * *$ & $\begin{array}{r}-0.0353 \\
(0.002)\end{array}$ & $* * *$ & $\begin{array}{r}-0.0305 \\
(0.002)\end{array}$ & $* * *$ & $\begin{array}{r}-0.0333 \\
(0.002)\end{array}$ & $* * *$ & $\begin{array}{r}-0.0292 \\
(0.002)\end{array}$ & $* * *$ \\
\hline Observations & \multicolumn{4}{|c|}{65,514} & \multicolumn{4}{|c|}{95,130} & \multicolumn{4}{|c|}{103,770} & \multicolumn{4}{|c|}{100,399} \\
\hline $\begin{array}{l}\text { Panel B } \\
\text { In-Kind (IK) }\end{array}$ & $\begin{array}{r}-0.0461 \\
(0.004) \\
\end{array}$ & $* * *$ & $\begin{array}{r}-0.0440 \\
(0.004) \\
\end{array}$ & $* * *$ & $\begin{array}{r}-0.0673 \\
(0.003) \\
\end{array}$ & $* * *$ & $\begin{array}{r}-0.0653 \\
(0.003) \\
\end{array}$ & $* * *$ & $\begin{array}{r}-0.0854 \\
(0.003) \\
\end{array}$ & $* * *$ & $\begin{array}{r}-0.0653 \\
(0.003) \\
\end{array}$ & $* * *$ & $\begin{array}{r}-0.0860 \\
(0.004) \\
\end{array}$ & $* * *$ & $\begin{array}{r}-0.0855 \\
(0.004) \\
\end{array}$ & $* * *$ \\
\hline Nursing Home IK (NHI) & $\begin{array}{c}-0.0575 \\
(0.003)\end{array}$ & $* * *$ & $\begin{array}{c}-0.0547 \\
(0.003)\end{array}$ & $* * *$ & $\begin{array}{r}-0.0565 \\
(0.002)\end{array}$ & $* * *$ & $\begin{array}{r}-0.0548 \\
(0.002)\end{array}$ & *** & $\begin{array}{r}-0.0605 \\
(0.002)\end{array}$ & $* * *$ & $\begin{array}{r}-0.0617 \\
(0.002)\end{array}$ & $* * *$ & $\begin{array}{r}-0.0617 \\
(0.003)\end{array}$ & $* * *$ & $\begin{array}{c}-0.0663 \\
(0.003)\end{array}$ & $* * *$ \\
\hline Nursing Home V (NHV) & $\begin{array}{c}0.0461 \\
(0.002)\end{array}$ & $* * *$ & $\begin{array}{c}0.0446 \\
(0.002)\end{array}$ & $* * *$ & $\begin{array}{r}0.0565 \\
(0.002)\end{array}$ & $* * *$ & $\begin{array}{r}0.0520 \\
(0.002)\end{array}$ & $* * *$ & $\begin{array}{r}0.0668 \\
(0.002)\end{array}$ & $* * *$ & $\begin{array}{r}0.0598 \\
(0.002)\end{array}$ & $* * *$ & $\begin{array}{r}0.0623 \\
(0.002)\end{array}$ & & $\begin{array}{r}0.0559 \\
(0.002)\end{array}$ & $* * *$ \\
\hline Day Care Centre IK (DCCI) & $\begin{array}{r}0.005 \\
(0.002)\end{array}$ & & $\begin{array}{c}0.003 \\
(0.002)\end{array}$ & & $\begin{array}{r}0.000 \\
(0.001)\end{array}$ & & $\begin{array}{r}0.000 \\
(0.001)\end{array}$ & & $\begin{array}{r}-0.001 \\
(0.001)\end{array}$ & & $\begin{array}{r}-0.001 \\
(0.001)\end{array}$ & & $\begin{array}{r}0.000 \\
(0.002)\end{array}$ & & $\begin{array}{r}0.000 \\
(0.002)\end{array}$ & \\
\hline Day Care Centre V (DCCV) & $\begin{array}{r}0.0031 \\
(0.001)\end{array}$ & $* * *$ & $\begin{array}{r}0.0026 \\
(0.001)\end{array}$ & $* * *$ & $\begin{array}{c}0.0033 \\
(0.001)\end{array}$ & $* * *$ & $\begin{array}{r}0.0028 \\
(0.001)\end{array}$ & $* * *$ & $\begin{array}{c}0.0024 \\
(0.001)\end{array}$ & $* * *$ & $\begin{array}{c}0.0018 \\
(0.001)\end{array}$ & $* * *$ & $\begin{array}{r}0.0035 \\
(0.001)\end{array}$ & $* * *$ & $\begin{array}{c}0.0029 \\
(0.001)\end{array}$ & $* * *$ \\
\hline Home Care IK (HCI) & $\begin{array}{c}-0.0136 \\
(0.002)\end{array}$ & $* * *$ & $\begin{array}{c}-0.0135 \\
(0.002)\end{array}$ & $* * *$ & $\begin{array}{r}-0.0277 \\
(0.002)\end{array}$ & $* * *$ & $\begin{array}{c}-0.0261 \\
(0.002)\end{array}$ & $* * *$ & $\begin{array}{r}-0.0361 \\
(0.002)\end{array}$ & $* * *$ & $\begin{array}{r}-0.0310 \\
(0.002)\end{array}$ & $* * *$ & $\begin{array}{r}-0.0349 \\
(0.002)\end{array}$ & $* * *$ & $\begin{array}{c}-0.0304 \\
(0.002)\end{array}$ & $* * *$ \\
\hline Home Care V (HCV) & $\begin{array}{r}-0.0010 \\
(0.001)\end{array}$ & & $\begin{array}{l}-0.0013 \\
(0.001)\end{array}$ & $* *$ & $\begin{array}{r}-0.0010 \\
(0.001)\end{array}$ & & $\begin{array}{r}-0.0012 \\
(0.001)\end{array}$ & $* *$ & $\begin{array}{r}0.0008 \\
(0.001)\end{array}$ & & $\begin{array}{r}0.0005 \\
(0.001)\end{array}$ & & $\begin{array}{r}0.0017 \\
(0.001)\end{array}$ & $* * *$ & $\begin{array}{r}0.0012 \\
(0.001)\end{array}$ & $* *$ \\
\hline Observations & \multicolumn{4}{|c|}{65,514} & \multicolumn{4}{|c|}{95,130} & \multicolumn{4}{|c|}{103,770} & \multicolumn{4}{|c|}{100,399} \\
\hline
\end{tabular}

Notes: bootstrapped standard errors in every second row.

$* * *$ indicates $1 \%$ significance. $* * 5 \%$ and $* 10 \%$.

Table A7: CCI, CHI and Corresponding Contributions for Different LTC Services

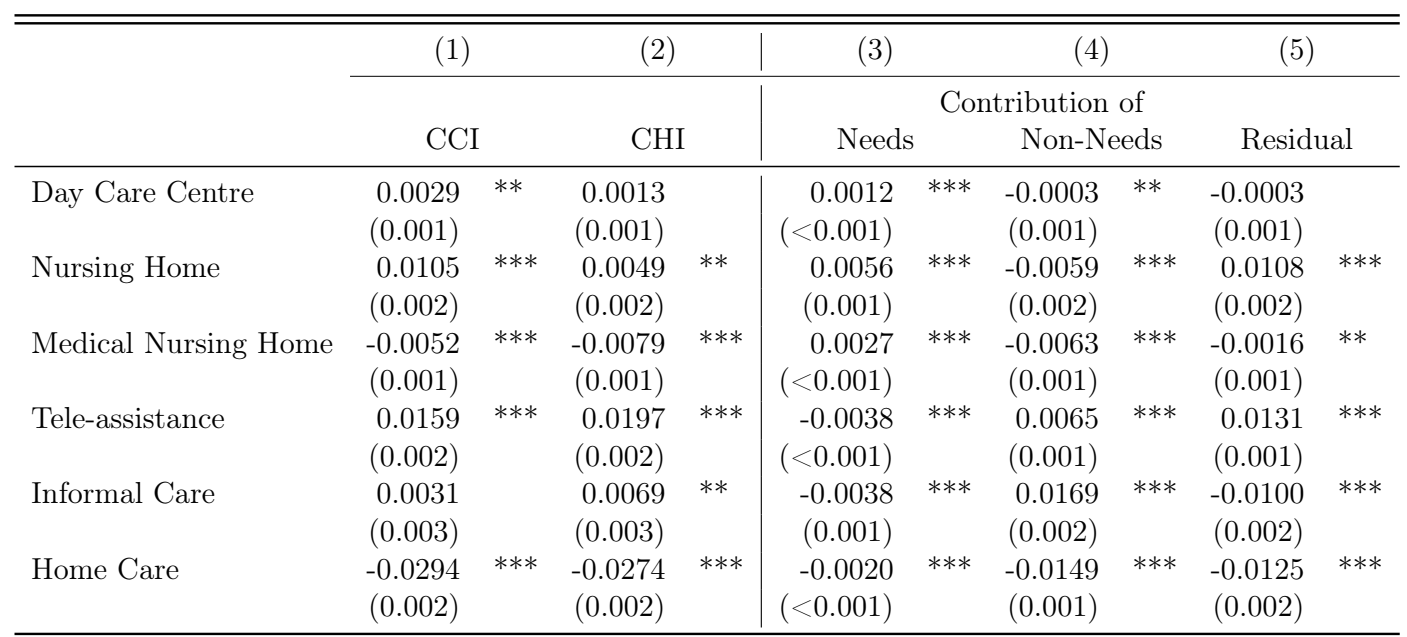

Notes: number of observations: 138,742. This table takes only the first non-missing observation per individual (78 $8 \%$ of claimants stick to the first chosen benefit). Bootstrapped standard errors in every second row.

*** indicates $1 \%$ significance, ${ }^{* *} 5 \%$ and $* 10 \%$. 
Table A8: Waiting Time to Access a Nursing Home (in Months), by Years and Providers

\begin{tabular}{|c|c|c|c|c|c|c|c|c|c|c|c|c|}
\hline & $(1)$ & $(2)$ & $(3)$ & $(4)$ & (5) & $(6)$ & $(7)$ & (8) & (9) & (10) & (11) & $(12)$ \\
\hline & & 2011 & & & 2012 & & & 2013 & & & 2014 & \\
\hline & All & In-Kind & Voucher & All & In-Kind & Voucher & All & In-Kind & Voucher & All & In-Kind & Voucher \\
\hline \multicolumn{13}{|l|}{ Panel A: Whole Sample } \\
\hline Mean & 19.66 & 16.79 & 23.83 & 19.96 & 18.14 & 22.23 & 20.73 & 19.67 & 22.15 & 21.87 & 21.98 & 21.66 \\
\hline Median & 16 & 14 & 20 & 17 & 16 & 18 & 17 & 17 & 17 & 18 & 19 & 15 \\
\hline Observations & 11,594 & 6,859 & 4,735 & 17,627 & 9,808 & 7,819 & 21,920 & 12,560 & 9,360 & 22,584 & 14,902 & 7,682 \\
\hline \multicolumn{13}{|l|}{ Panel B: Inflow only } \\
\hline Mean & 18.37 & 16.78 & 20.58 & 18.54 & 18.04 & 19.02 & 20.32 & 19.89 & 20.76 & 22.01 & 22.98 & 20.35 \\
\hline Median & 15 & 14 & 16 & 15 & 16 & 14 & 17 & 18 & 16 & 18 & 19 & 14 \\
\hline Observations & 4,859 & 16.78 & 2,041 & 6,640 & 3,279 & 3,361 & 8,705 & 4,390 & 4,315 & 10,480 & 6,651 & 3,829 \\
\hline
\end{tabular}

Notes: observations with zero waiting time are excluded.

Table A9: CI and HI in Time to Access Nursing Homes

\begin{tabular}{|c|c|c|c|c|c|c|c|c|c|c|c|c|c|c|c|c|}
\hline & \multicolumn{2}{|c|}{$(1)$} & \multicolumn{2}{|c|}{$(2)$} & \multicolumn{4}{|c|}{ (4) } & \multicolumn{4}{|c|}{ (6) } & \multicolumn{4}{|c|}{$(7)$} \\
\hline & \multicolumn{4}{|c|}{2011} & \multicolumn{4}{|c|}{2012} & \multicolumn{4}{|c|}{2013} & \multicolumn{4}{|c|}{2014} \\
\hline & $\mathrm{CI}$ & & \multicolumn{2}{|l|}{ HI } & \multicolumn{4}{|c|}{ HI } & \multicolumn{4}{|c|}{$\mathrm{HI}$} & \multicolumn{4}{|c|}{$\mathrm{HI}$} \\
\hline $\begin{array}{l}\text { Panel A: Whole sample } \\
\text { NH Waiting Time (NHWT) }\end{array}$ & $\begin{array}{r}0.0193 \\
(0.004)\end{array}$ & $* * *$ & $\begin{array}{r}0.0252 \\
(0.004)\end{array}$ & $* * *$ & $\begin{array}{r}0.0093 \\
(0.003)\end{array}$ & $* *$ & $\begin{array}{r}0.0159 \\
(0.003)\end{array}$ & $* * *$ & $\begin{array}{r}0.0022 \\
(0.003)\end{array}$ & & $\begin{array}{r}0.0089 \\
(0.003)\end{array}$ & $* *$ & $\begin{array}{r}-0.0026 \\
(0.003)\end{array}$ & & $\begin{array}{r}0.0034 \\
(0.003)\end{array}$ & \\
\hline Observations & \multicolumn{4}{|c|}{11,608} & \multicolumn{4}{|c|}{17,649} & \multicolumn{4}{|c|}{21,944} & \multicolumn{4}{|c|}{22,607} \\
\hline $\begin{array}{l}\text { Panel B: Inflow only } \\
\text { NH Waiting Time (NHWT) }\end{array}$ & $\begin{array}{r}0.0108 \\
(0.006)\end{array}$ & $*$ & $\begin{array}{r}0.02 \\
(0.006)\end{array}$ & $* * *$ & $\begin{array}{r}0.0002 \\
(0.005)\end{array}$ & & $\begin{array}{r}0.009 \\
(0.005)\end{array}$ & * & $\begin{array}{r}-0.0187 \\
(0.005)\end{array}$ & $* * *$ & $\begin{array}{r}-0.0116 \\
(0.005)\end{array}$ & $* *$ & $\begin{array}{r}-0.014 \\
(0.004)\end{array}$ & $* * *$ & $\begin{array}{r}-0.0051 \\
(0.004)\end{array}$ & \\
\hline NH-IK Waiting Time (NHWTI) & $\begin{array}{r}-0.0013 \\
(0.007)\end{array}$ & & $\begin{array}{r}0.0114 \\
(0.007)\end{array}$ & & $\begin{array}{l}0.0053 \\
(0.006)\end{array}$ & & $\begin{array}{l}0.0148 \\
(0.006)\end{array}$ & $* *$ & $\begin{array}{r}0.0045 \\
(0.006)\end{array}$ & & $\begin{array}{r}0.0119 \\
(0.006)\end{array}$ & $* *$ & $\begin{array}{r}-0.0006 \\
(0.005)\end{array}$ & & $\begin{array}{r}0.0075 \\
(0.005)\end{array}$ & \\
\hline NH-V Waiting Time (NHWTV) & $\begin{array}{r}-0.0136 \\
(0.011)\end{array}$ & & $\begin{array}{r}-0.017 \\
(0.01)\end{array}$ & & $\begin{array}{r}-0.0214 \\
(0.008)\end{array}$ & $* *$ & $\begin{array}{r}-0.0167 \\
(0.008)\end{array}$ & $* *$ & $\begin{array}{r}-0.0265 \\
(0.008)\end{array}$ & $* * *$ & $\begin{array}{r}-0.0228 \\
(0.007)\end{array}$ & $* * *$ & $\begin{array}{r}-0.0432 \\
(0.008)\end{array}$ & $* * *$ & $\begin{array}{r}-0.0427 \\
(0.008)\end{array}$ & *** \\
\hline Observations & \multicolumn{4}{|c|}{4,787} & \multicolumn{4}{|c|}{6,824} & \multicolumn{4}{|c|}{8,637} & \multicolumn{4}{|c|}{10,386} \\
\hline
\end{tabular}

Notes: bootstrapped standard errors in every second row.

$* * *$ indicates $1 \%$ significance. $* * 5 \%$ and $* 10 \%$. 